\title{
An Electron Microscopic Study of the Olfactory Mucosa in the Bat and Rabbit
}

\author{
Masaru Yамамото
}

\author{
Received October 6, 1975
}

Summary. The olfactory epithelium and the olfactory gland were electron microscopically observed in the bat and rabbit.

1. In spite of abundant tubular components of sER, the supporting cells show no cytological signs of secretory activity. Numerous long irregular microvilli which are protruded from the supporting cells into the mucous film covering the olfactory epithelium contain no axial filaments. From the outer leaflet of the plasma membrane covering these cells and their microvilli, numerous polypoid processes are projected into the mucous film. These newly identified delicate processes with an apical vesicular swelling about $200 \AA$ in diameter may be involved in an extension of surface area or in a microapocrine release of unknown substance.

2. Olfactory cell perikaryon extends an apical dendrite forming an olfactory vesicle (better to be called "dendritic bulb") and a basal neurite or axon. Basal bodies of olfactory cilia are contained in the dendritic bulb and provided with 3 types of appendages: one or occasionally 2 striated conical basal feet directed toward the center of the dendritic bulb, an occasional $1.2 \mu$ long striated rootlet and 9 spokes which extend between the distal end of each of 9 triplets of the basal body and the surface plasma membrane.

3. The present study has first disclosed the so-called "large dense-cored vesicles" about 750-1,000 $\AA$ in diameter in the perikaryons and axons of olfactory cells. The dendrite and axon contain numerous neurotubules and mitochondria, but no neurofilaments. Cytological differences between dendrite and axon consist in that the former contains scattering free ribosomes but no large dense-cored vesicles, while the latter contains no free ribosomes but some large dense-cored vesicles.

4. Undifferentiated basal cells containing no tonofilaments, which are supposed to differentiate through mitosis into "intercalated cells," are proposed in this paper. Electron-lucent intercalated cells show cy tological characteristics of undifferentiated cells, and may probably be precursors of both olfactory and supporting cells.

5. In the bat and rabbit olfactory gland, the presence of an intraepithelial excretory duct surrounded by proper epithelial cells lacking in secretory function seems doubtful. The olfactory gland seems to lack a basement membrane. Secretory cells are in various stages of the secretory cycle, but no distinct cell types have been distinguished. Secretory granules of low density with dense cores support, together with their histochemical properties, the mucous nature of the olfactory gland in both species, though the rich tubular elements of sER may suggest a possible peculiar nature of their secretions. Rabbit secretory cells contain "dense rodlets," which are probably derived from the tubular sER. They are discharged by apocrine process into the glandular lumen.

The olfactory mucosa, especially the olfactory epithelium, has been studied by many authors with the light (Kolmer, 1972; Allison, 1953; BANG and BANG, 1959 etc.) and electron microscope (ReEse, 1965; OKano, 1965; OKano et al., 1967; SeIFERT and Ule, 1967; FrISCH, 1967; ANDRES, 1969; GRAZIADEI, 1972 etc.). However, several questions still remain unanswered. On the other hand, the olfactory gland (Bowman) has been studied in detail by ToyodA (1960) with the light microscope in various mammalian species, but only a few electron microscopical investigations (BREIPOHL, 
1972) have been available on this important consituent of the olfactory mucosa, and detailed electron microscope studies are required for the elucidation of its fine structure. In the present study, the olfactory mucosa, including the olfactory gland, was observed with the electron microscope in the bat and rabbit to make some contributions to the knowledge of the fine structure of the mammalian olfactory mucosa.

\section{Materials and Methods}

Six wild bats, Rhinolophus ferrum-equinum nippon, of both sexes captured in June and November in mountainous districts of Gunma and Chiba Prefectures and domestic male albino rabbits were used for this study. From decapitated or nembutalanesthetized bats and rabbits, olfactory mucosae were excised and immediately immersed into the fixative (2.5\% glutaraldehyde, $0.1 \mathrm{M}$ phosphate buffer, $\left.\mathrm{pH} 7.4,0^{\circ} \mathrm{C}\right)$. After 2 hrs' fixation, these samples were washed 3 times in cold glucose buffer $(0.1 \mathrm{M}$ phosphate buffer, $7 \%$ glucose) and left overnight in the same buffer at $5^{\circ} \mathrm{C}$ (MizuHIRA, 1973). Immediately after the fourth washing in cold glucose buffer, they were postfixed $1 \mathrm{hr}$ in $1 \% \mathrm{OsO}_{4}$ dissolved in the same cold buffer. The samples were dehydrated as usual through an ethanol series, embedded in Epon 812 and sectioned with the Porter-Blum ultramicrotome. Sections were stained with uranyl acetate saturated in water and then in SAto's lead solution (SAto, 1968). To determine the chemical nature (mucous or albuminous) of the secretory product of the olfactory gland, additional samples of bat's olfactory mucosa were fixed and stained with ruthenium red according to LUFT (1971). All these samples were observed under the electron microscope JEM-100C. Thicker sections of Epon-embedded specimens were stained with $0.1 \%$ toluidine blue in $0.1 \mathrm{M}$ phosphate buffer ( $\mathrm{pH}$ 7.4) and observed under the optical microscope.

For light microscopic examinations, specimens excised from bat and rabbit olfactory mucosa were fixed in 10\% neutralized formalin or in Zenker-formalin and prepared into celloidin or paraffin sections to be stained with hematoxylin-eosin, PAS, chromic acid-Schiff reaction of BAUER and alcian blue 8GX (ScOTT and Droling, 1965).

\section{Result}

The olfactory mucosa comprises the olfactory epithelium and the subjacent connective tissue layer, the lamina propria and the tela submucosa, that is, the deeper layer of the connective tissue. The olfactory epithelium belongs to a typical pseudostratified columnar epithelium and is composed of (1) tall and slender olfactory or neuroepithelial cells, (2) supporting cells which are as tall as the former, and (3) short basal cells which line along the basal surface of the olfactory epithelium in a single layer (Fig. 1). There are authors who have identified the fourth and fifth type cells (OKano, 1965; Okano et al., 1967; Andres, 1969). The connective tissue layer, lamina propria and tela submucosa, contain branched tubular or tubuloalveolar olfactory glands (Bowman) each with a short unbranched excretory duct which perpendicularly perforates the olfactory epithelium to open on the free surface of the latter. The connective tissue contains, besides Bowman's glands, unmyelinated fila olfactoria of the olfactory nerve running between the acini of the gland and several kinds of connective tissue cells such as lymphocytes in variable numbers.

The free surface of the olfactory epithelium is covered, as is widely known, with 


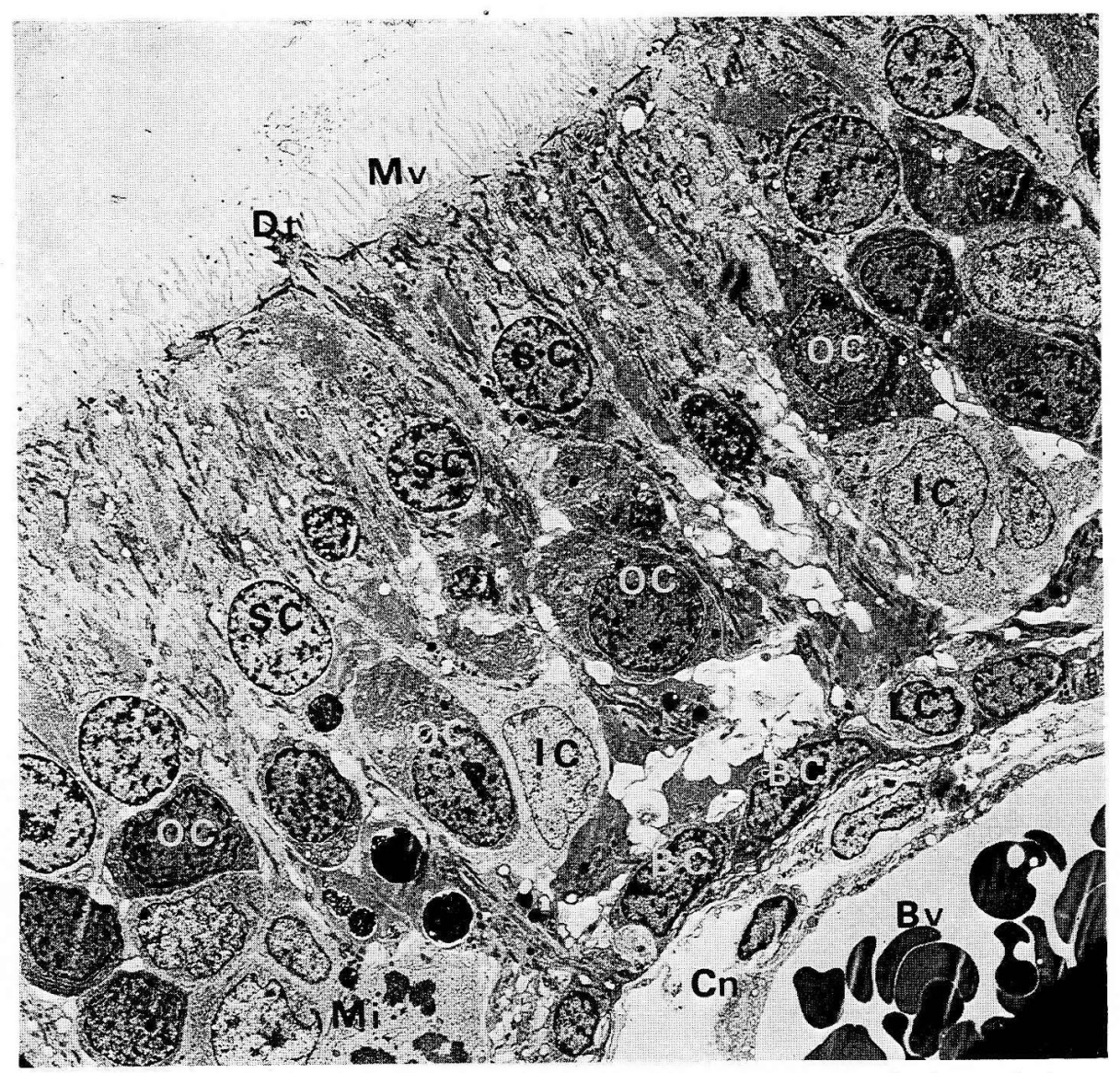

Fig. 1. Survey electron photomicrograph of the bat olfactory epithelium in the vertical section. $B C$ basal cells, $B v$ blood vessel containing erythrocytes, $C n$ connective tissue, $D t$ dendritic bulb (olfactory vesicle), IC intercalated or interstitial cells, $L C$ light cell in the basal cell layer, $M i$ mitosis of the intercalated cell, $M v$ microvilli of supporting cells, $O C$ olfactory cells, SC supporting cells which contain in infranuclear portions many dense bodies of variable sizes (lipofuscin granules). $\quad \times 2,600$

a thick mucous film, which is thought, in mammalian species, to be mainly formed by secretion discharged from olfactory glands (Fig. 2). By light microscopy a brush border-like structure of the olfactory epithelium has been revealed to be protruded into the basal layer of the mucous film. As proved by electron microscopy, this may correspond to well-developed microvilli of supporting cells.

\section{Olfactory Epithelium}

\section{Supporting cell}

The supporting cell (Fig. 1,3,4) is a slender columnar cell with a wide apical or distal portion and a tenuous proximal portion which tapers toward the basement membrane to form a foot process. The basement membrane and the basal surface of the foot process are connected with hemidesmosomes (Fig. 10, 12). 


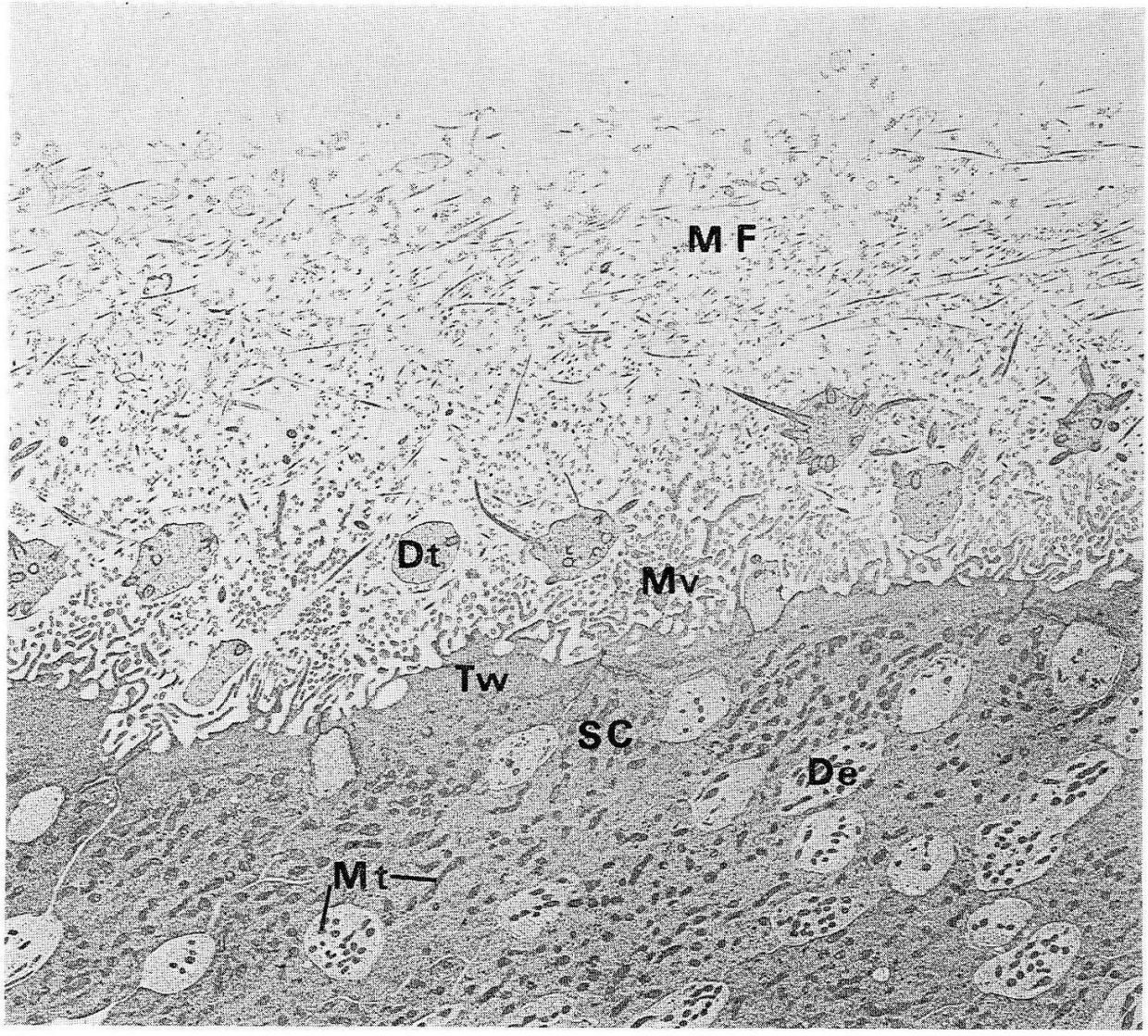

Fig. 2. Survey electron photomicrograph of the mucous film (layer) covering the bat olfactory epithelium and the distal border of the olfactory epithelium sectioned transversely but somewhat obliquely. Within the mucous film $(M F)$ dendritic bulbs (olfactory vesicles) (Dt) containing several basal bodies of olfactory cilia, microvilli of supporting cells $(M v)$, thick as well as thin portions of olfactory cilia the latter of which show many rounded swellings. In the olfactory epithelium profiles of dendrites $(D e)$ of olfactory cells are seen being separated from each other by supporting cells $(S C) . \quad M t$ mitochondria, $T w$ terminal webs of supporting cells. $\times 5,400$

Between the wide apical portion and the tenuous proximal portion, an oval nucleus is present. From the apical surface of the cell forming the free surface of the olfactory epithelium a number of irregular, and partially branched microvilli of considerable length extend into the mucous film. They show on the whole a seeweedlike appearance as described by Окало (1965) (Fig. 1-4). They contain no axial filaments. In the present study, a unique and delicate structure has been revealed on the plasma membrane of the microvilli of supporting cells. This hitherto unknown structure is represented by numberless fine bubble-like or drumstick-shaped processes protruding at approximately right angles probably from the outer leaflet of the plasma membrane. The basal part (neck) of these processes is more or less constricted, and the apical end is swollen into a vesicle measuring about $200 \AA$ in diameter (Fig. 2-5). The limiting membrane of each process is very thin and seems different from the 


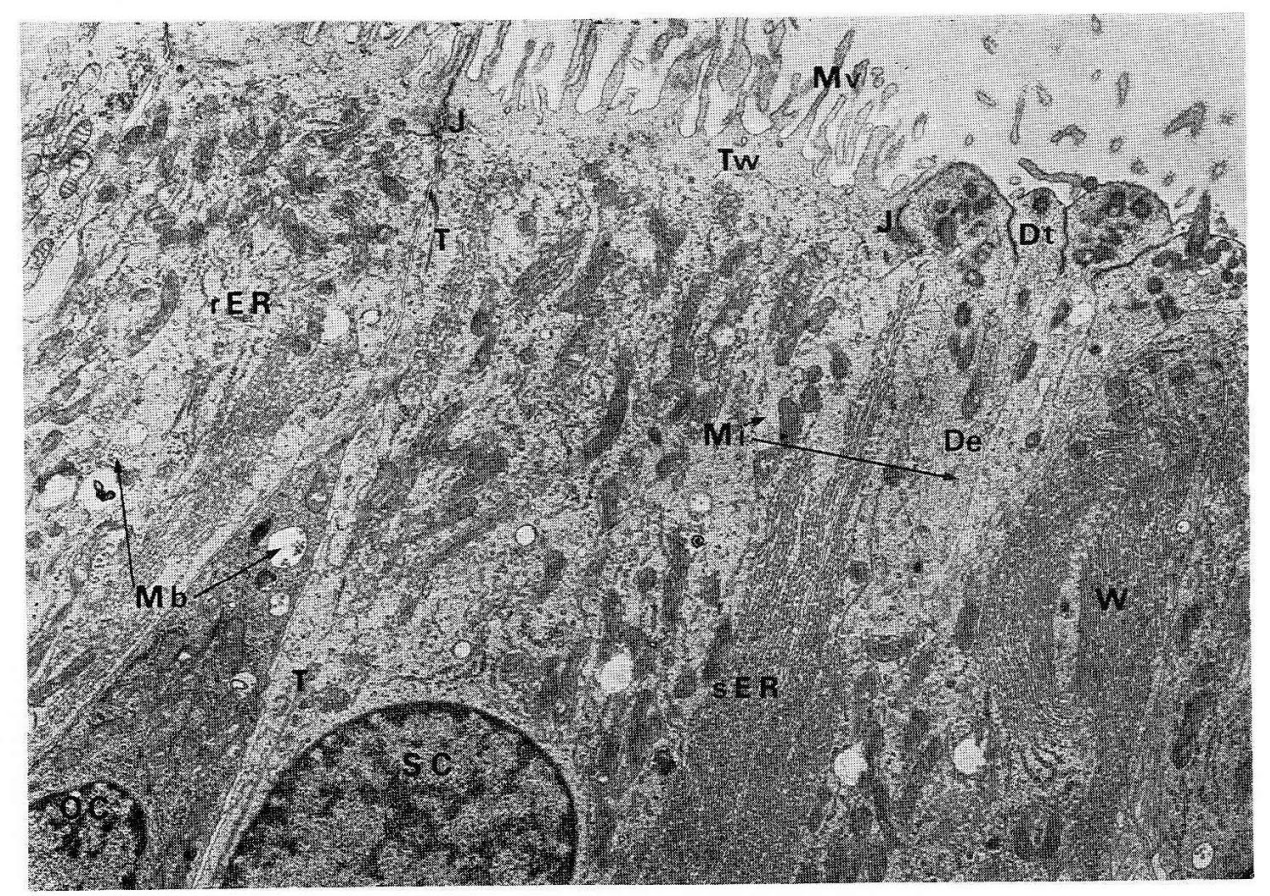

Fig. 3. Distal portions (supranuclear and apical portions) of supporting cells (SC), a perikaryon $(O C)$ and 4 dendrites $(D e)$ as well as dendritic bulbs (olfactory vesicles) (Dt) of olfactory cells are seen in a vertical section of the bat olfactory epithelium. The distal portions of suporting cells contain numerous mitochondria, abundant smooth endoplasmic reticulum (sER) and a small amount of rough endoplasmic reticulum (rER). Tubular components of sER show parallel arrays and occasional whorl-like configurations $(W)$. The perikaryon of an olfactory cell contains mitochondria, rER and free ribosomes (Nissl substance): the dendritic bulbs contain several basal bodies and a small number of mitochondria and dendrites mitochondria and longitudinally oriented microtubules (Mi). $J$ junctional complex, $M b$ multivesicular body, $M v$ microvilli, $T$ tonofilament bundle, $T w$ terminal web. $\times 7,500$

plasma membrane of a trilaminal structure (Fig. 5). The delicate processes are also identified on the plasma membrane limiting the free surface of the supporting cell itself. In both bat and rabbit, these fine processes have been demonstrated, but somewhat less numerous in the rabbit.

Immediately beneath the free surface, supporting cells possess a terminal web in which cell organelles are almost lacking (Fig. 2-4). At the level of this layer, neighboring supporting cells are connected with junctional complexes; zonula occludens or the tight junction found just beneath the free surface (Fig. 3) is immediately followed by zonula adherens and macula adherens (desmosome), to which fine filaments of the terminal web and tonofilament bundles of the cytoplasm are concentrated (Fig. 3). Desmosomes are occasionally found also in deeper portions of the epithelium more or less away from the junctional complex. Between the supporting cell and olfactory vesicle of the olfactory cell as well as between adjacent olfactory vesicles, the same junctional specialization are observed (Fig. 3).

In the supranuclear and apical cytoplasm beneath the terminal web, namely in 
the widest and most cytoplasm-rich portion of the supporting cell, there are concentrated cell organelles, i.e., centriole, mitochondria, smooth and rough endoplasmic reticulum, free ribosomes, microtubules and tonofilaments. The Golgi complex and multivesicular bodies are also located in the supranuclear area. Neverthless, no cytological signs suggesting production of secretory granules have been detected either in bat or in rabbit supporting cells.

Richness in smooth endoplasmic reticulum is one of the conspicuous cytological characteristics of bat and rabbit supporting cells; abundant fine tubular profiles of smooth endoplasmic reticulum are found mainly along the lateral surface of the cell, making dense parallel arrays of variable thickness (Fig. 1, 3). In the central area of the cytoplasm, tubules of smooth endoplasmic reticulum are arranged in loose networks and frequently make basket-like investments around the mitochondria (Fig. 3). As some investigators reported (FRISCH, 1967), tubules of smooth endoplasmic reticulum are occasionally concentrically disposed to exhibit whorl-like lamellar configurations of variable sizes (Fig. 3).

Rough-surfaced endoplasmic reticulum is much less developed in both bat and rabbit supporting cells. Organized tubular or cisternal constituents of rough endoplasmic reticulum are loosely distributed for the most part in the central area of the cytoplasm. Direct transition of tubules of rough endoplasmic reticulum into those of smooth endoplasmic reticulum losing attached ribosomes is not infrequently observed (Fig. 3, 7B).

Free ribosomes are not numerous. Forming polysomes, they are mainly found in areas in which rough endoplasmic reticula are distributed.

Considerably numerous mitochondria are concentrated in the apical and supranuclear regions of supporting cells, and they also extend into the infranuclear region and the foot process (Fig. 1, 8, 10,12). They are filamentous or rod-shaped in profile and elongated approximately along the long axis of the cell.

Multivesicular bodies are found in the supranuclear region singly or few in number; they are in general small in size and contain a few small vesicles (Fig. 3).

A few microtubules of about $200 \AA$ thickness and a few tonofilament bundles run among mitochondria and components of endoplasmic reticulum almost parallel to the long axis of the supporting cells, and some of the tonofilament bundles anchor with one end in desmosomes as mentioned above (Fig. 3). The Golgi apparatus is found in the supranuclear area, and composed of some Golgi complexes. They consist of typical lamellae and vesicles, but vacuoles are scarcely found. Signs suggesting the formation of secretory granules in Golgi complexes have never been confirmed. A single centriole is occasionally found in the apical cytoplasm beneath the terminal web.

Plasma membranes of neighboring supporting cells are closely apposed in parallel to each other with an even intercellular space, about $200 \AA$ wide. Intercellular interdigitations are nowhere detectable (Fig. 1-4). The same parallel apposition of plasma membranes takes place between neighboring dendrites of olfactory cells and apical and supranuclear portions of supporting cells as seen in the vertical section of the olfactory epithelium (Fig. 3, 7B). In a transverse section of the olfactory epithelium (Fig. 2), round or oval cross sections of the dendrites of olfactory cells are seen as if they are embedded between angular cross sections of distal portions of supporting cells, and they are separated from each other by the cytoplasmic masses of the latter. 


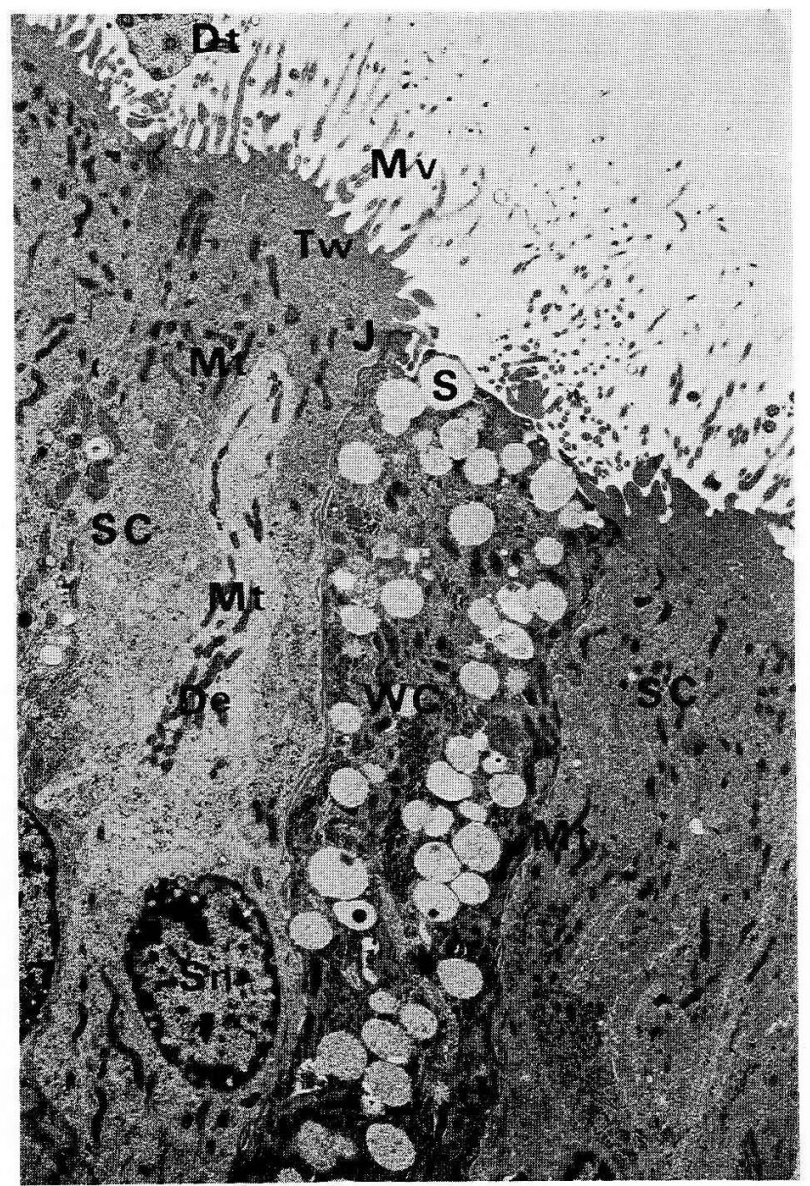

Fig. 4. Distal portions of supporting cells $(S C)$ and an epithelial cell of the intraepithelial excretory duct $(W C)$ of the olfactory gland are shown in a vertical section of the bat olfactory epithelium. The duct epithelial cell contains many electron-lucent secretory granules $(S)$ some of which possess an electron dense round core. $D e$ and $D t$ dendrite and dendritic bulb of olfactory cells, $J$ junctional complex, $M t$ mitochondria, $M v$ microvilli, $S n$ a supporting cell nucleus showing tangentially sectioned nuclear pores. $\times 4,600$

In the cross section also, the cells are apposed to each other with an approximately $200 \AA$ wide intercellular space in between.

The nuclei of supporting cells are ovoid or round. They are usually situated above the middle of the height of the olfactory epithelium, thus shifted somewhat toward the distal or apical side of the olfactory epithelium; they are seldom displaced from this position. The paranuclear cytoplasm is generally narrow and contains a few cell organelles, for example a few mitochondria and occasional tonofilament bundles passing through this region (Fig. 1,3). The chromatin is partially condensed along the 
inner surface of the nuclear envelope, and another part is concentrated in the internal karyoplasm into a loose and irregular network. The nucleolus is not conspicuous, and nuclear pores are considerably numerous (Fig. 3, 4).

In the infranuclear portion and in the foot process, a small number of filamentous and rod-shaped mitochondria are distributed along the long axis, and there are areas in which tubular constituents of smooth endoplasmic reticulum are concentrated (Fig. 8, 10,12). In the infranuclear region, similar, whorl-like accumulations of tubules of smooth endoplasmic reticulum are occasionally observed as in the supranuclear region. Components of rough endoplasmic reticulum, free ribosomes and tonofilament bundles running along the long axis are also encountered.

In the infranuclear cytoplasm, there occur considerably numerous large and small dense bodies, probably lipofuscin granules (Fig. 1, 8, 10, 12,14). For a long time it has been believed that the olfactory mucosa may contain a yellow pigment which would induce a yellow color of the olfactory mucosa, though without precise knowlege about the location of the pigment. It it possible that these infranuclear lipofuscin granules of the supporting cell may probably play an essential role in yellow coloring of the olfactory mucosa.

In Figure 8, cross sections of the proximal portions (infranuclear portion and foot process) of supporting cells together with those of perikaryons and axons of olfactory cells are seen. They are characterized by the light appearance of the cytoplasm, tubular profiles of smooth endoplasmic reticulum and poorness in components of rough endoplasmic reticulum as well as free ribosomes. Between neighboring supporting cells and between supporting cells and olfactory cells, the close relationship is confirmed by means of the same parallel appositions of plasma membranes with an approximately $200 \AA$ wide intercellular space without intercellular interdigitations. Along the parallel apposed plasma membranes there occur desmosomes here and there (Fig. 8).

Epithelial cells of the intraepithelial excretory duct of the olfactory gland are occasionally observed among supporting cells. Their apical surface facing the mucous film is lacking in microvilli. In their relatively dark cytoplasm, numerous filamentous and rod-shaped mitochondria elongated along the long axis of the cell, and cisternae of rough endoplasmic reticulum are distributed, being intermingled with numerous secretory granules, which show the same cytological properties as those found in the secretory cells of the olfactory gland. Between an epithelial cell of the intraepithelial duct and an adjacent supporting cell, the same junctional complexes as observed between olfactory epithelial cells are present (Fig. 4). In the bat, the epithelial cell may form rather simple infoldings against adjacent supporting cells (Fig. 4), which are not observed in the rabbit. As to the excretory duct of the olfactory gland, a detailed description will be found below.

\section{Olfactory cell}

As widely accepted, olfactory cells (sensory or receptor cells) have been taken for bipolar neurons. They are columnar cells as tall as the supporting cells, but as a whole much more slender than the latter, except for the perikaryon which contains a spherical nucleus thus making a round swelling. The location of the nuclei in the olfactory epithelium is somewhat variable, but they are always situated between the 


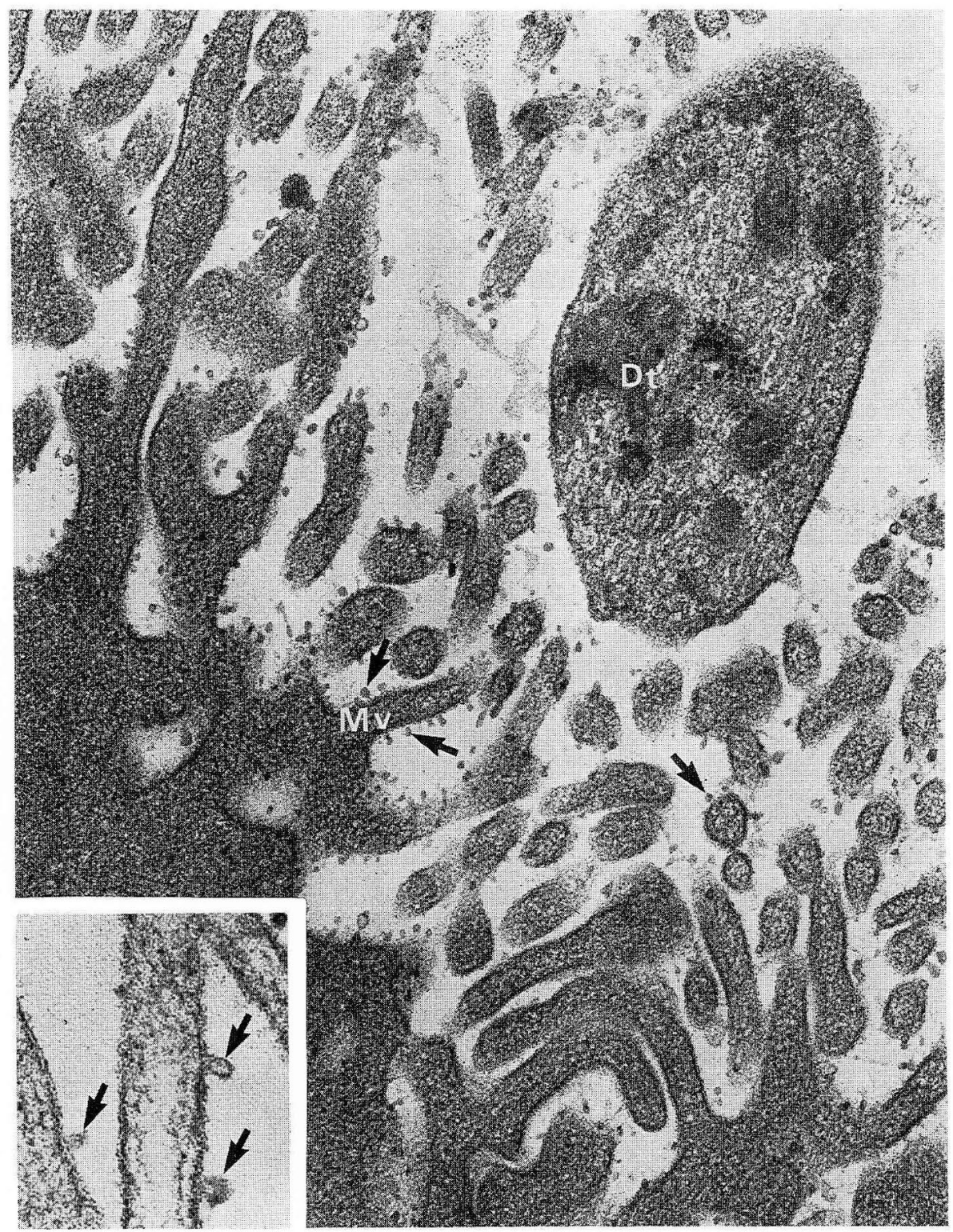

Fig. 5. High power view of microvilli $(M v)$ of a bat supporting cell. Along the surface of microvilli and free surface of the supporting cell many delicate bubble-like or poly poid processes are protruded almost at right angles from the outer leaflet of the trilaminal plasma membrane (arrows). The basal part of these processes is constricted and the apical end makes a vesicular swelling. Dt dendritic bulb of an olfactory cell. $\times 54,000$ Inset: Higher magnification of bubble-like processes (arrows) protruded from microvilli. Note they arise from the outer leaflet of plasma membrane bounding microvilli. $\quad \times 99,000$ 
nuclei of supporting cells and those of basal cells (Fig. 1). The distal slender cytoplasmic portion which extends between the free surface of the olfactory epithelium and the perikaryon is called dendrite (Fig. 1, 3,7). The distal end of this portion makes a conspicuous, oval or spherical swelling which extends beyond the free surface of the olfactory epithelium, being found in the mucous film covering the free surface (Fig. 1-4, 6, 7). Although this swelling is usually called the olfactory vesicle, we would like to propose in the present paper to designate it as "dendritic bulb," because "olfactory vesicle" may readily remind us of much smaller structures such as the smooth vesicles contained in it. The constricted proximal portion of this dendritic bulb, the neck, is connected side by side with the distal end of the neighbouring supporting cell or occasionally with the neck of the abutting olfactory cell by means of a junctional complex, as already described above in the chapter on the supporting cell (Fig. 3, 7).

The proximal tenuous cytoplasmic portion extending from the perikaryon toward the basal surface of the olfactory epithelium is referred to as the axon (neurite) of the bipolar neuron. Axons finally penetrate the basement membrane of the olfactory epithelium to enter the connective tissue layer of the olfactory mucosa, where they are gathered into large bundles, fila olfactoria, and approach the olfactory bulb.

\section{a. Dendritic bulb (olfactory vesicle) and dendrite}

Oval or spherical dendritic bulbs measure approximately $1-2 \mu$ in diameter and contain in the cytoplasm a number of microtubules, basal bodies of olfactory cilia and smooth vesicles, but scanty mitochondria (Fig. 1-3, 6, 7).

Olfactory cilia (hairlets) originate from the basal bodies lying perpendicularly beneath the plasma membrane lining the dendritic bulb and extend radially into the mucous film covering the olfactory epithelium (Fig. 2,6). Olfactory cilia embedded in their entire length within the mucous film are different from ordinary motile cilia in the following characteristics: they are composed of a short proximal thicker portion and a long distal thinner portion; the thick portion measures approximately $1 \mu$ in length and is as thick as the ordinary motile cilium. It extends almost radially from the dendritic bulb. The thin portion arises from the attenuated distal end of the thick portion, runs for a long distance within the mucous film almost parallel to the free surface of the olfactory epithelium and then bends in the direction away from the latter to arrive finally at the superficial layer of the mucous film (Fig. 2).

The long thin portion is provided with spindle-shaped swellings of an unknown number which are found along its long axis at unknown intervals (Fig. 2). These swellings may correspond to the spindle-shaped swellings by OкANo (1965), and the dilations of the ciliary extension by FRISCH (1965). The question, whether the thin portion of the olfactory cilium of bat and rabbit might terminate in a dilation (swelling), which was revealed by OKano (1965) in the olfactory cilium of the dog has not been solved in this study. Olfactory cilia protruding from the dendritic bulbs in the direction almost parallel to the free surface of the olfactory epithelium and numberless microvilli ascending from the supporting cells almost perpendicularly toward the free border of the mucous film form a complex meshwork or reticular structure crossing each other within the latter (Fig. 2).

As seen in a longitudinal section shown in Figure 6A, the thick portion of the 
the ciliated epithelium: Longitudinally oriented peripheral tubules on both sides beneath limiting plasma membranes of the thick portion and 2 paired central tubules in the axis. Proximal ends of central tubules, however, do not reach the basal body of the cilium, disappearing before entering the neck of the thick portion. On the contrary, peripheral tubules are continuous through the neck with the wall or shell of the basal body. In a cross section of the thick portion (Fig. 6B) it is shown that 9 peripheral tubules are doublets, which are circularly arranged at regular intervals along the limiting plasma membrane of the thick portion, and that cross sections of olfactory cilium has the same fine structure as that of an ordinary motile cilium of

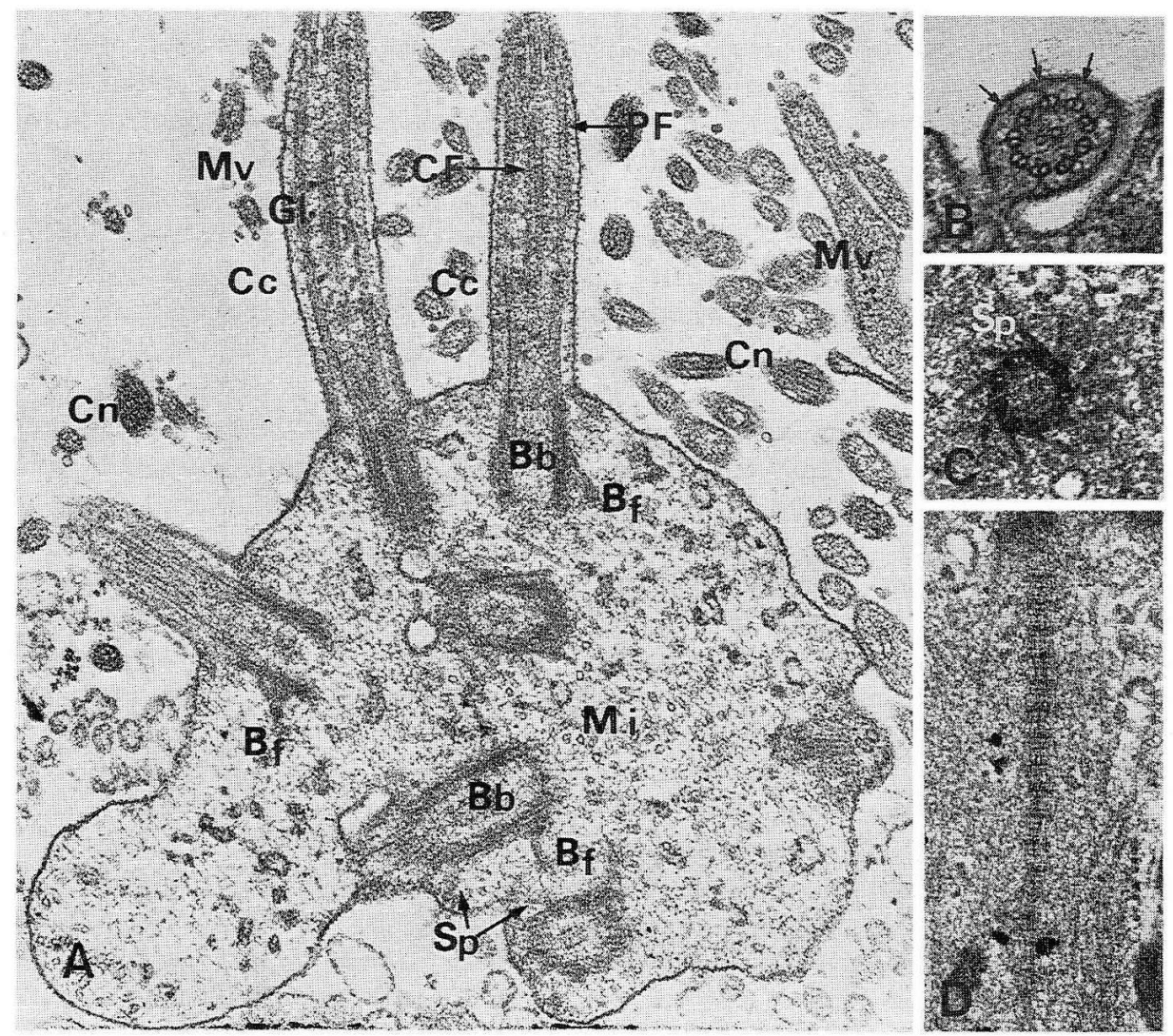

Fig. 6. A. Dendritic bulb containing several basal bodies $(B b)$ some of which are longitudinally sectioned and protrude respectively a thick portion of olfactory cilium $(C c)$. Around the dendritic bulb and the thick portions of olfactory cilia, profiles of thin portions $(C n)$ of olfactory cilia and microvilli $(M v)$ of the supporting cell are observed. Profiles of microvilli are characterized by associated delicate bubble-like processes. $B f$ basal foot, $C F$ central fibers (tubules), $G l$ glycogen particles, $M i$ microtubules, $P F$ peripheral fiber, $S p$ transitional fiber or spoke. $\times 38,000$ B. Cross section of a thick portion of olfactory cilium showing the fibril pattern $9+2$. From each of the 9 doublets a dense line or bridge with a $\mathrm{Y}$-shaped configuration radiates toward the plasma membrane of the cilium (arrow). $\times 54,000 \quad$ C. Cross section of the distal end of a basal body. From the outer surface of each of 9 triplets embedded in the electron dense circular wall of the basal body one fibrous process i.e., spoke $(S p)$ is projected radially and exhibits on the whole a pin-wheel

configuration. $\times 40,000$ D. Cross-striated rootlet composed of fine filaments. $\times 40,000$ 
the paired central tubules are situated side by side in the center of the circle of peripheral doublets. The presence of central tubules suggests that this cross section is not made across the neck of the thick portion, but across a more or less distal portion away from the latter.

From the center of the outer surface of each peripheral doublet a fine dense line

the radial arm or bridge described by REESE (1965)_- arises radially toward the plasma membrane of the thick portion, and on the way each bifurcates into two branches, the peripheral ends of which attach to the plasma membrane exhibiting a $\mathrm{Y}$-shaped configuration (Fig. 6B). These dense filamentous structures are revealed in a cross section of the neck of ordinary motile cilia, in which the paired central tubules are lacking. In the present study, these $\mathrm{Y}$-shaped configurations have been detected frequently in the cross sections of the thick portion, containing paired central tubules. This probably suggests that these configurations may be distributed, in contrast to the finding of OKANO (1965), in wide extent of the thick portion. In bat olfactory cilia, as shown in Figure 7A, there has occasionally been found such a cross section of the thick portion, in which two or four pairs of central tubules are identified.

In the cross sections of the distal thin portion of olfactory cilia, no peripheral doublet is identified anywhere, while a small number of single tubules are detected scattering irregularly within a small round cytoplasmic area encircled by the plasma membrane.

In the spindle-shaped swellings found along the length of the thin portion, only a few single tubules running beneath the limiting plasma membrane are found, while in the interior, a few vesicles of variable sizes are frequently encountered (Fig. 2).

Basal bodies of olfactory cilia of the bat and rabbit do not show any peculiar features as compared with those of ordinary epithelial cilia. They represent short cylinders standing perpendicularly to the plasma membrane of the dendritic bulb. In longitudinal sections, they appear somewhat attenuated toward the distal portion near the originating part of the cilium (Fig. 6A). As mentioned above, peripheral tubules of the thick portion of the cilium extend into the electron-opaque wall or shell of the basal body. The less dense interior of the cylinder, called the cavity, seems to contain in the center a small elliptic vesicle elongated longitudinally (Fig. 6A) which is, however, indistinct in appearance because of the obscurity of its limiting membrane. A similar vesicle or granule was observed by REESE (1965) in the basal bodies of frog olfactory cilia. In cross sections, basal bodies appear as circular configurations composed of an electron dense peripheral wall or shell and an electron lucent interior or cavity, and in the electron dense wall, 9 triplet tubules are circularly arranged at regular intervals (Fig. 6C), which may continuously extend into the peripheral doublet tubules of the thick portion of olfactory cilium.

Basal bodies of olfactory cilia of bat and rabbit possess three types of accessory structures or appendages; spokes or transitional fibers, basal foot and rootlet (fiber).

Spokes are 9 electron dense fibrous structures measuring about $120 \mathrm{~m} \mu$ in length, which extend obliquely between the distal end of the basal body and the plasma membrane lining the transitional part between the neck of the cilium and the dendritic bulb (Fig. 6A). As observed in a cross section of the basal body sectioned in a plane passing almost tangentially to the surface plasma membrane and through the distal end of the basal body, 9 spokes originate respectively from the outer surface 
of the 9 triplets of the basal body and extend radially toward the surrounding cytoplasm, so that they show on the whole a pinwheel-like configuration (Fig. 6C). Each spoke is pointed at the end part. These structures have probably been erroneously reported by Okano et al. (1967) as basal feet.

The basal foot represents, both in longitudinal and transverse sections of the basal body, an electron dense conical process with a wide basal surface on the outer surface of the proximal portion of the basal body and with the attenuated end part toward the surrounding cytoplasm. The basal foot (Fig. 6A, 7A) consists of a bundle of fine filaments, which exhibit cross striations similar to those of the rootlet fiber described below (Fig. 7A). Each basal body usually bears one basal foot oriented toward the definite direction. In the section of the dendritic bulb cut in a plane parallel to the surface of the olfactory epithelium, all basal feet arc oriented toward the center of the dendritic bulb arising from basal bodies arranged circularly beneath the plasma membrane of the dendritic bulb (Fig. 7A). Occasionally basal bodies
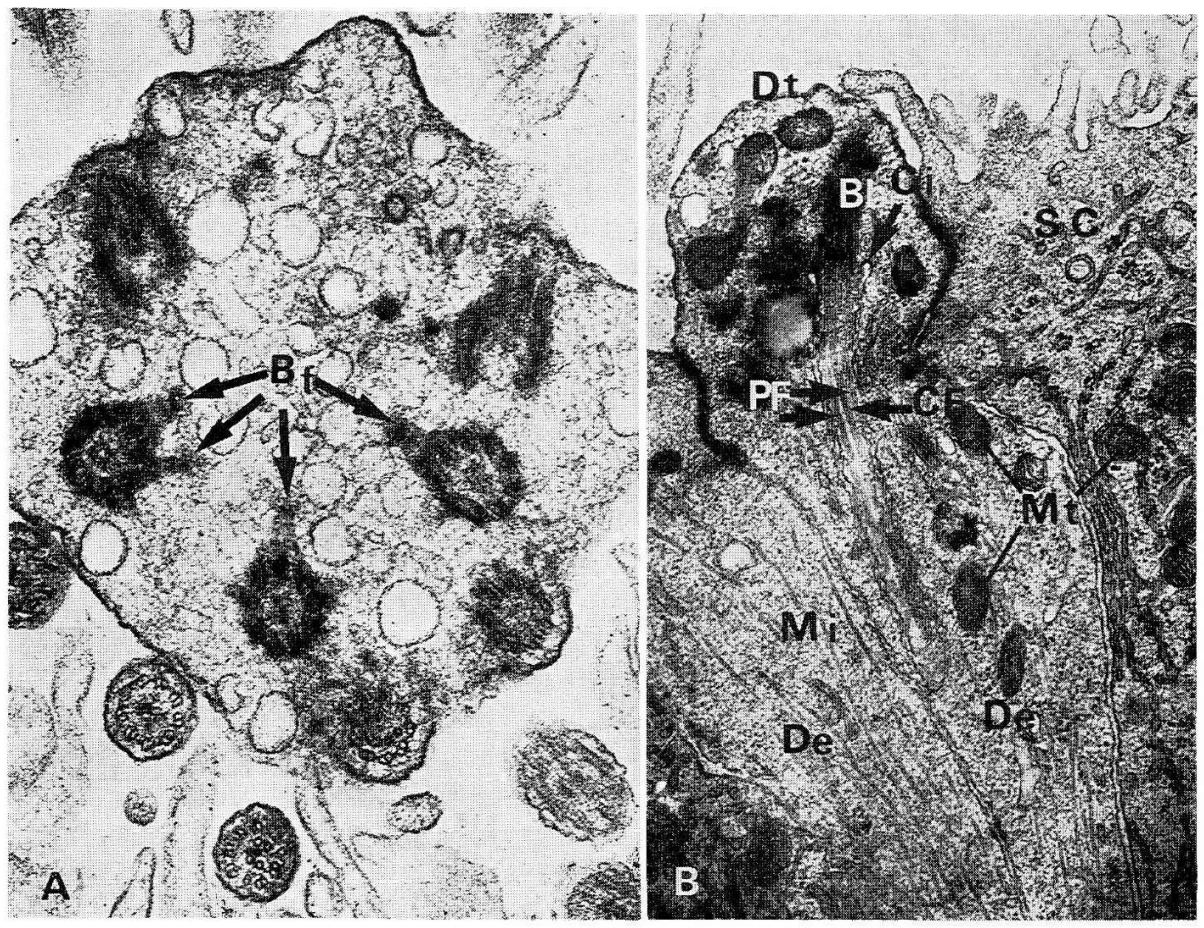

Fig. 7. A. Dendritic bulb sectioned transversely or in parallel to the epithelial free surface. Three basal bodies arranged circularly in the peripheral zone of the dendritic bulb protrude one or two conical striated basal feet $(B f)$ toward the center of the dendritic bulb which contains besides basal bodies many smooth vesicles of variable sizes. At the bottom center of this figure a cross section of a thick portion of olfactory cilium is seen which possesses 2 or 4 pairs of central tubules (abnormal fibril pattern). $\times 40,000$ B. Olfactory cilium extending from a basal body $(B b)$ within the dendritic bulb $(D t)$ toward the reversed direction into the dendrite $(D e)$ of an olfactory cell. It contains central $(C F)$ and peripheral tubules $(P F)$ corresponding to the thick portion of olfactory cilium and is enwrapped by a ciliary vesicle $(C i)$. Mi microtubule, $M t$ mitochondria, $S C$ supporting cell. $\times 20,000$ 
bearing double basal feet are found, and in such a case, both basal feet are oriented either toward the same direction (Fig. 7A) or toward the opposite direction.

The tertiary accessory structure of the basal body is a rootlet which arises from the proximal end of the basal body wall and extends straight toward the neck of the dendritic bulb tapering gradually toward the pointed proximal end (Fig. 6D). The rootlet is not a constant appendage for every basal body of bat and rabbit olfactory cilia, and so it is encountered only occasionally in sections of dendritic bulbs. It measures approximately $1.2 \mu$ in length, and is composed of a bundle of fine filaments, which show cross striations comparable with those of the basal foot, spaced approximately $700 \AA$ apart (Fig. 6D).

The exact number of basal bodies which are contained in one dendritic bulb (olfactory vesicle), that is, the exact number of olfactory cilia sent out from a bulb is difficult to count. In Figure 2, many dendritic bulbs are encountered, one of them containing 8 basal bodies. This is the largest counted number of basal bodies contained in a dendritic bulb in the present study. On the basis of this counting and the numbers reported in literature, we have come to the conclusion that the number of basal bodies containing in a dendritic bulb of bat and rabbit might presumably attain from 20 to 30 in total.

The present study disclosed, in a bat dendritic bulb, a curious olfactory cilium which extends from basal body beneath the plasma membrane of the dendritic bulb for a long distance in a reversed direction toward the deep portion of the dendrite beyond the neck of the dendritic bulb. In the longitudinal section of this cilium (Fig. 7B), both the central and peripheral tubules can be distinguished, proving that this may correspond to a thick portion of an olfactory cilium. The plasma membrane limiting this cilium is reflected at the originating part from the basal body into that of the ciliary vesicle which encompasses the cilium within the cytoplasm; a narrow closed space between the two plasma membranes represents the lumen of the ciliary vesicle. These findings agree with those of the early stage of the ciliary development (HUBERT et al., 1974).

The reason why the olfactory cilium has developed in the reversed direction into the cytoplasm of the olfactory cell may perhaps be found in the circumstance that the distal end of the basal body which is distined to develop a ciliary bud has been erroneously disposed toward the interior of the dendritic bulb. This hypothesis may also presuppose the presence of polarity in the basal body.

Cytoplasm of the dendritic bulb contains, basides many basal bodies and occasional rootlets, numerous microtubules running in several directions, variable numbers of smooth vesicles and scanty mitochondria (Fig. 2, 6, 7). As seen in Figure 6A, numerous round or elongated profiles of the microtubules are concentrated near the basal bodies. These microtubules are supposed to be continuous with those found in the dendrite.

Dendrites of olfactory cells are thought to be cylindrical in shape, as shown in Figure 2, and their round or oval cross sections are embraced by cytoplasm of supporting cells, thus being separated from each other. Not infrequently, a few dendrites are closely adjoined side by side, and their dendritic bulbs are connected at the neck by means of junctional complexes or terminal bars (Fig. 3, 7B), and plasma membranes of lateral surfaces of the dendrites adjacent to the dendritic bulbs are 
apposed parallel, separated from each other by an intercellular space about $200 \AA$ wide. The question whether this parallel membrane apposition continues to the more proximal portion of the dendrite or not, can not be answered in this study. It is, however, possible that supporting cell cytoplasm may intervene between proximal portions of neighboring dendrites to separate them from each other, but as shown in Figure 8, parallel membranes are frequently apposed between neighboring perikaryons.

Main cytoplasmic organelles in the dendrites of olfactory cells are numerous microtubules, which are oriented longitudinally and almost in parallel to each other, thus extending into the dendritic bulb (Fig. 3,7B), and relatively numerous rodshaped and filamentous mitochondria elongated generally along the long axis of the dendrite (Fig. 1, 3, 4,7B). Besides these main organelles, smooth vesicles are detected in a small number, and also large multivesicular bodies are occasionally found in the transitional area between dendrite and perikaryon (Fig. 3). Free ribosomes, which are also found in a small number in the dendritic bulb (Fig. 3, 7B), increase gradually toward the proximal portion of the dendrite, and in the area abutting on the perikaryon a considerable number of polysomes are detectable (Fig. 3).

\section{b. Perikaryon}

Perikaryons of olfactory cells are conspicuous spindle-shaped, nucleated swellings, tapering toward the distal direction into dendrites and toward the proximal direction into axons, and they are disposed generally in deeper portions of the olfactory epithelium than the nuclei of supporting cells. Round or oval nuclei of olfactory cells are characterized by a conspicuously large spherical nucleolus of a high electron density, although the distribution of the chromatin in karyoplasm almost agrees with that in the supporting cell (Fig. 8). The electron density of perikaryonal cytoplasm (neuroplasm) may chiefly depend on richness in organized components of rough endoplasmic reticulum and free ribosomes, both of which together compose the so-called Nissl substance (Fig. 1, 3, 8). In certain perikaryons, flattened cisternae of rough endoplasmic reticulum are stacked in parallel to make a lamellar arrangement (Fig. 1, 8, 13). In general, Nissl substance of perikaryon of the olfactory bipolar neuron is rich in free ribosomes in contrast to the relatively small amount of attached ribosomes on the cisternal membrane of the rough endoplasmic reticulum, so that there occur, between cisternae of rough endoplasmic reticulum, numerous free ribosomes making polysomes (Fig. 3, 8, 13). This particular proportion of free ribosomes to membrane-attached ribosomes of rough endoplasmic reticulum is thought, as is widely accepted, to be a morphological characteristic of Nissl substance in neurons.

Perikaryon contains numerous rod-shaped mitochondria. As they are elongated longitudinally (Fig. 3), cross sections of perikaryons (Fig. 8) commonly show their round profiles. Golgi complex is found in the supranuclear region (Fig. 8), and is composed of stacks of Golgi lamellae (cisternae) and numerous Golgi vesicles, of which relatively many are coated. Frequently large multivesicular bodies occur in the supranuclear region and near the transitional part between perikaryon and dendrite; they are larger than those found in supporting cells, and contain many small vesicles (Fig. 3, 8). Further, dense bodies of variable sizes are detected, and some of them contain vacuoles and show complex configuration and structure, suggesting that they have been elaborated as the consequence of coalescence of several dense bodies (Fig. 8). 


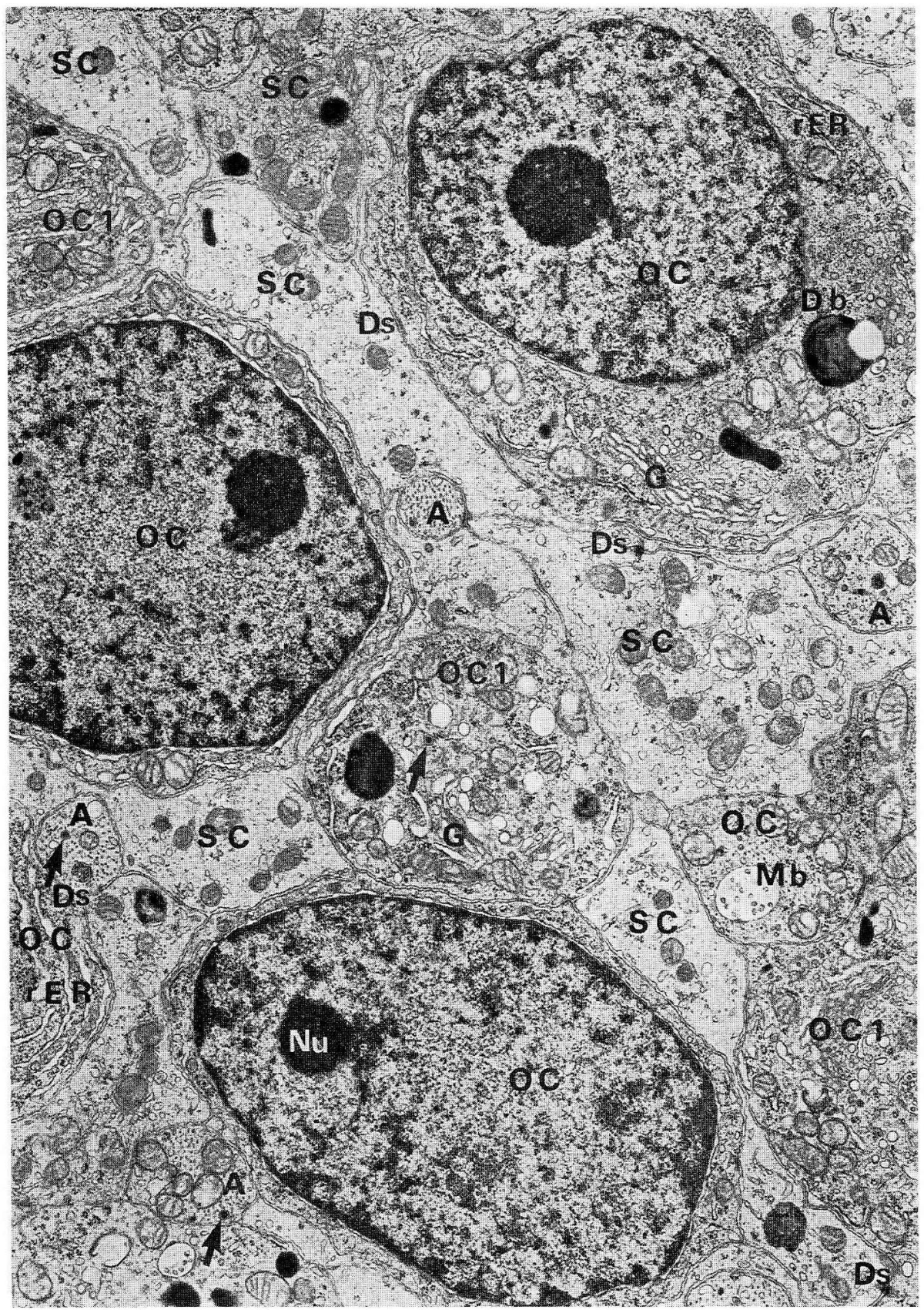

Fig. 8. Transverse section of the bat olfactory epithelium cut along a plane close to the perikaryons $(O C)$ of olfactory cells. Among them cross sections of the supranuclear regions $(O C 1)$ of perikaryons as well as axons $(A)$ are seen. Between them infranuclear portions of supporting cells $(S C)$ intervene which are characterized by tubules of sER. Mitochondria are cut transversely and show round profiles. Axons contain, besides mitochondria, many neurotubules cut transversely. $D b$ dense body, $D$ s desmosome, $G$ Golgi complex, $M b$ multivesicular body, $N u$ nucleolus, $r E R$ rough endoplasmic reticulum (Nissl substance) in the perikaryon. Arrows point at large densc cored vesicles. $\times 12,700$ 
These dense bodies may probably be lipofuscin granules.

Large dense cored vesicles measuring $750-1,000 \AA$ in diameter, which are usually found in perikaryons of neurons, axoplasm of nerve fibers and synaptic terminals elsewhere, are occasionally identified in the perikaryons of bat and rabbit olfactory cells in the vicinity of the Golgi complex (Fig. 8, center).

Identical large dense cored vesicles are also detected in the axoplasm of axons arising from the perikaryon (Fig. 8); they are not found in dendrites. This finding supports the view that large dense cored vesicles are elaborated in Golgi complexes in perikaryons of olfactory cells (neurons), and released into axoplasm to be sent by means of the axon flow toward synaptic terminals in the olfactory bulb.

As seen in cross sections exhibiting the perikaryons of olfactory cells, they are rather irregularly distributed within the olfactory epithelium, being separated from each other by cytoplasmic masses of supporting cells (Fig. 8). Not infrequently, however, they are found abutting directly on perikaryons, axons or dendrites of neighboring olfactory cells by means of the membrane apposition, in which, between parallel apposed plasma membranes, an intercellular space about $200 \AA$ in width is interposed, demonstrating here and there electron dense desmosomes (Fig. 8).

\section{c. Axon (neurite)}

The tapering proximal end of the perikaryon extends into a thin neurite (axon) aproximately $0.3 \mu$ in diameter (Fig. 8, 9). Cytoplasm (axoplasm) of the neurite contains no organized components of rough-surfaced endoplasmic reticulum and free ribosomes; main cytoplasmic organelles of the neurite are numerous microtubules (neurotubules) running longitudinally and a small number of mitochondria elongated also in a longitudinal direction. Besides these main organelles, a few large dense cored vesicles and smooth vesicles (about $0.15-0.2 \mu$ in diameter) of variable numbers are demonstrated. Neurofilaments have not been revealed in the axons of bat and rabbit olfactory receptors as in the dendrite including the dendritic bulb, and in perikaryon.

As shown in a cross section (Fig. 8), neurites are embraced by cytoplasmic layers of supporting cells and far separated from each other. Occasionally, however, the cross section of the neurite abut on that of perikaryon of the adjacent olfactory cell with the two membranes being apposed (Fig. 8, bottom left). In the basal region of olfactory epithelium, a number of neurites or axons are gathered in small bundles,

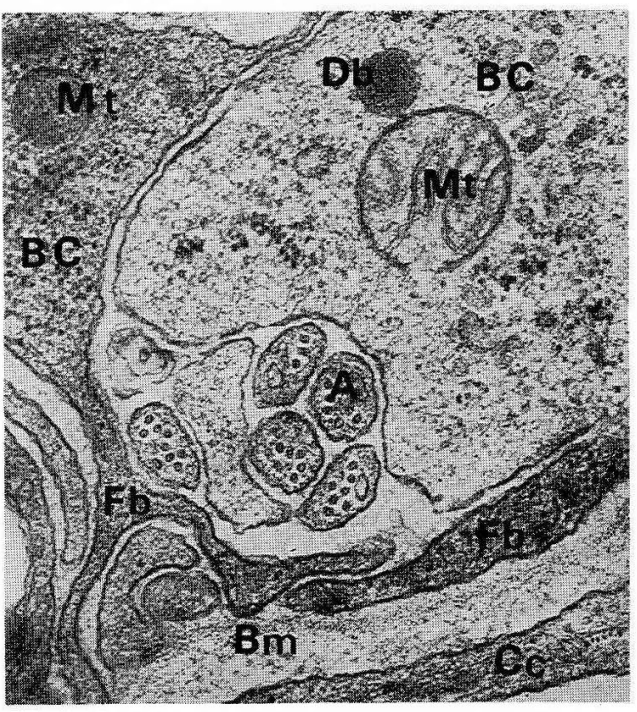

Fig. 9. Basal cells $(B C)$ and their cytoplasmic processes $(F b)$ which embrace a small bundle of axons $(A)$ of olfactory cells in between. Basal cell bodies and processes are rich in free ribosomes but contain no tonofilament bundles. Axons contain many neurotubules sectioned transversely. $B m$ basement membrane, $C c$ connective tissue cell, $D b$ dense body, $M t$ mitochondria. $\times 33,000$ which are embraced by basal cells (Fig. 9), just before penetrating the basement 
membrane of the olfactory epithelium.

\section{Basal cell}

Basal cells are arranged in a single layer along the basal surface of the olfactory epithelium (Fig. 1). They are low and angular cells of smaller sizes and extend many slender irregular cytoplasmic processes in variable directions, especially toward the basement membrane, some bifurcating into branches (Fig. 9, 10, 12). These processes extend between foot processes of supporting cells (Fig, 10, 12), and frequently interdigitate or elongate side by side in complicated fashions (Fig. 9, 12). Between these cytoplasmic processes and the cell body, compartments of wide intercellular space are formed, in which, as mentioned above, small bundles of axons of olfactory cells are contained before they advance into the underlying connective tissue layer (Fig. 9). The complex basal surface of the basal cell, however, makes a simple transverse straight contour parallel to the basement membrane, and is connected with the latter by hemidesmosomes (Fig. 11, 12). Between apposed plasma membranes of adjacent basal cells and between these and supporting cells, there occur desmosomes, to which tonofilament bundles of basal cells anchor. This is also the case with hemidesmosomes (Fig. 11).

Small nuclei of basal cells are mostly oval and elongated along the basal surface of the olfactory epithelium (Fig. 1, 10). The distribution pattern of chromatin in

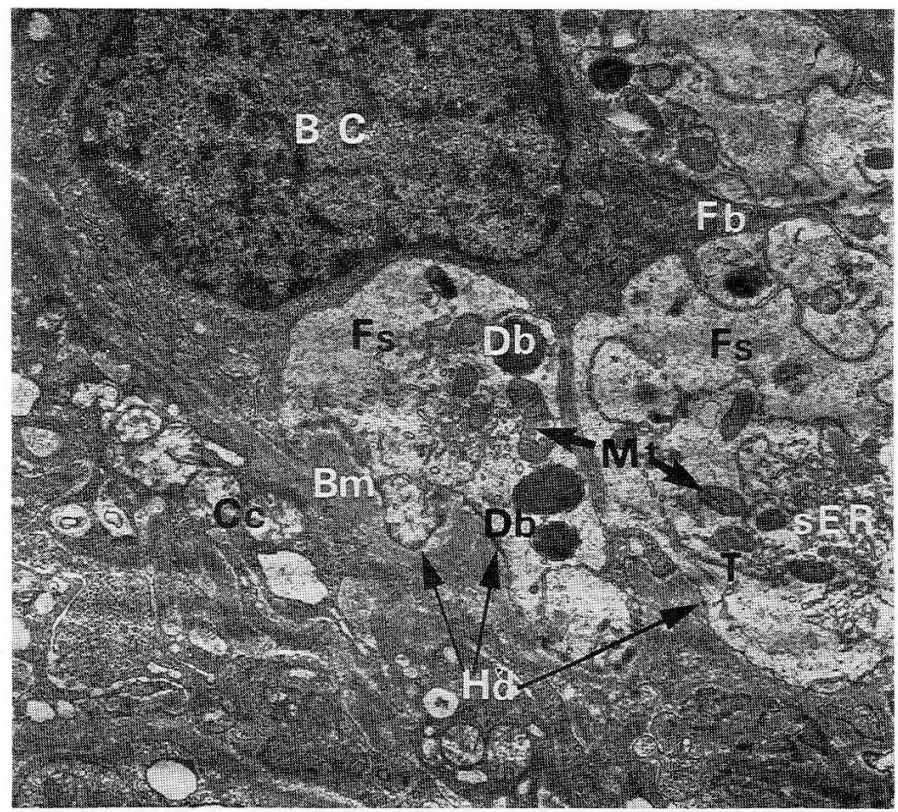

Fig. 10. Basal cell $(B C)$ and foot processes (FS) (cut obliquely) of supporting cells in the basal layer of bat olfactory epithelium. The basal cell sends out cytoplasmic processes $(F b)$ between the foot procosses. The foot processes are characterized by tubular components of $s E R$ and many dense bodies. Between the basement membrane $(B m)$ and foot processes many half-desmosomes $(H d)$ are noticed. $C c$ connective tissue cell, $M t$ mitochondria. $\quad \times 10,600$ 
nucleoplasm resembles that in the nuclei of the supporting and olfactory cells. They contain conspicuous nucleoli of irregular shapes and sizes either in the interior of the nucleus or on the nuclear envelope (Fig. 1). In the narrow cytoplasmic layer around the nucleus, there occur a number of round and rod-shaped profiles of mitochondria (Fig. 10), being distributed also in thick cytoplasmic processes; and abundant free ribosomes, some of which make polysomes, are widely distributed even in thin cytoplasmic processes (Fig. 9, 11). This conspicuous richness in free ribosomes represents one of the important characteristics of basal cells. By means of this, the basal cells are easily distinguishable from adjacent basal cytoplasmic regions of supporting cells which are characterized by richness in tubular constituents of smooth endoplasmic reticulum and dense bodies, probably lysosomes of variable sizes (Fig. 10, 12). By contrast, cisternae of rough endoplasmic reticulum are not numerous. They are confined in the cell body and in thick cytoplasmic processes (Fig. 10, 12). Besides these main organelles, small dense bodies, probably lysosomes, and an occasional small multivesicular body are demonstrated. The Golgi complex has not been revealed in the present study. As for tonofilaments, it has been proved that their development is considerably different from cell to cell (compare Fig. 9 to Fig. 11). They are gathered

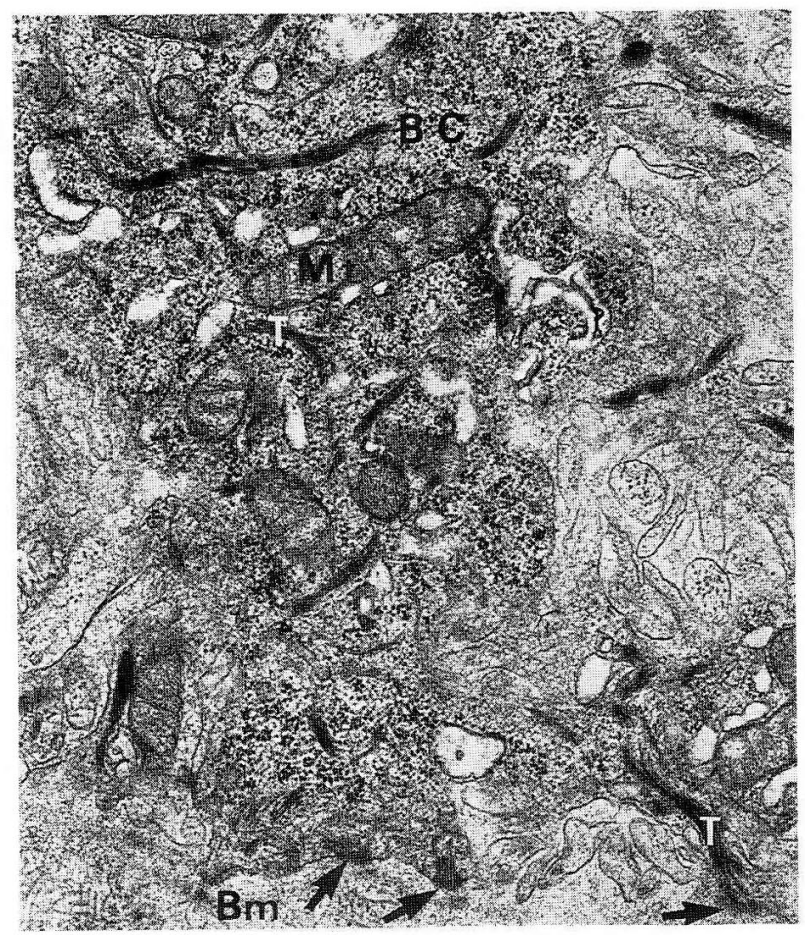

Fig. 11. Basal cell body $(B C)$ containing abundant free ribosomes (partially polysomes) and many tonofilament bundles $(T)$ which ramify and run in random directions. Between the basal surface of the cell body and the basement membrane $(B m)$ several half-desmosomes (arrows) are demonstrated to which

tonofilament bundles adhere. $M t$ mitochondria. $\times 20,000$ 


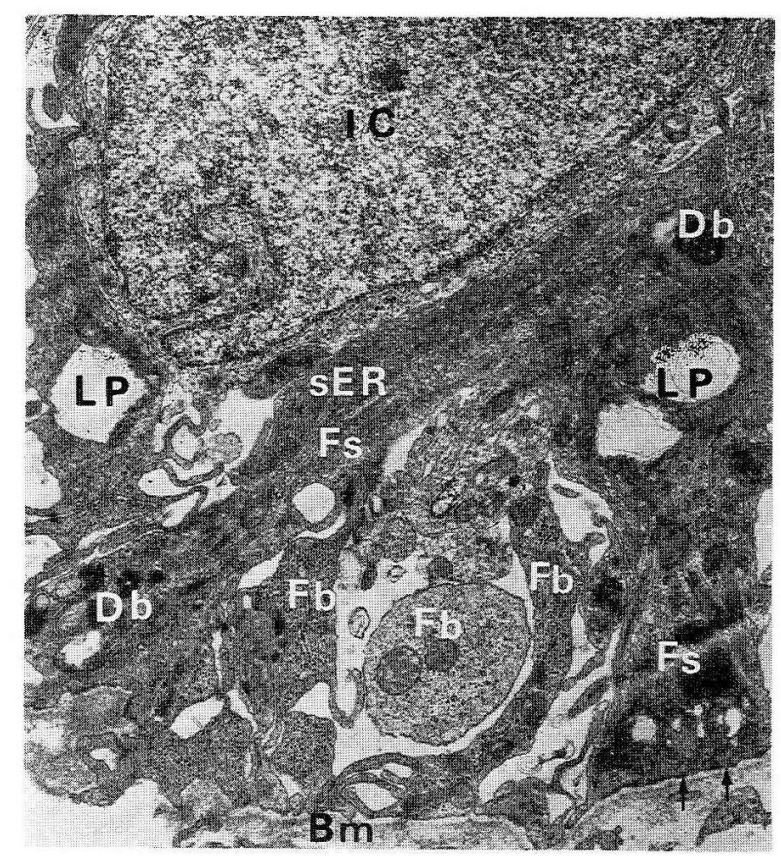

Fig. 12. Longitudinally sectioned basal feet $\left(F_{s}\right)$ of the supporting cell (bifurcated) rich in tubular components of $s E R$ and complicated cytoplasmic processes $(F b)$ of basal cells in the basal layer of bat olfactory epithelium. The basal surfaces of the basal feet and the basement membrane $(B m)$ are connected with many hemidesmosomes (arrows). $D b$ dense bodies in the basal feet of supporting cells, IC intercalated cell, $L p$ lipid droplet. $\times 10,600$

for the most part into bundles, which extend in random directions, ramifying in a simple fashion (Fig. 11). The tonofilament bundle which exists near a desmosome or hemidesmsome attaches by one end to the latter, as briefly mentioned above (Fig. 11).

In the basal layer of the olfactory epithelium, consisting of basal cells, mitotic divisions have not been demonstrated in the present study in either bat or rabbit.

\section{Interstitial or intercalated cell}

The present observation in bat olfactory epithelium has revealed that a number of irregular-shaped epithelial cells with pale cytoplasm are scattered between other epithelial cells as well as between the basal cell layer and the layer of perikaryons of olfactory cells (Fig. 1). Thus, they are confined to the interior of the olfactory epithelium and extend neither to the free surface nor to the basal surface of the latter. These cells are tentatively named "interstitial or intercalated cells" on account of their location. Their somewhat irregular-shaped nuclei also appear pale due to their poor chromatin content (Fig. 1, 12). They possess a small Golgi complex above the nucleus, a small number of short mitochondria scattered randomly in narrow cytoplasm and scanty cisternae of rough endoplasmic reticulum. The main cytoplasmic organelle seems to be abundant free ribosomes (Fig. 1, 10) and this suggests that the 
interstitial cell may represent an undifferentiated epithelial element. In the present study, two mitotic figures, probably of this cell type, have been demonstrated in the same location as usually occupied by the interstitial cell.

\section{Olfactory Gland (Bowman)}

In contrast to olfactory epithelium which has been minutely studied by numerous investigators, the olfactory gland has rarely been a subject of detailed light or electron microscopic study. Among these rare works the excellent light microscopic study of Toyoda (1960) is most valuable.

As to the type of olfactory gland, there are two different opinions; one assumes that it belongs to the simple branched tubular gland (ToyodA, 1960; BREIPoHL, 1972), and the other claims that it must be a simple branched tubulo-alveolar one (GRAZIADEI, 1972). In any case, these two types of gland are not so much different.

The question, whether or not the olfactory gland possesses a proper excretory duct surrounded by a peculiar epithelium, has not been ultimately answered. If present, the duct must be a short channel confined within the olfactory epithelium and perpendicularly penetrate the latter to open on its surface (ToYoDA, 1960). As already described in this study, epithelial cells of the excretory duct are occasionally detected within bat olfactory epithelium aligned side by side with supporting cells, but they contain characteristic secretory granules such as usually found in secretory cells of the olfactory gland (Fig. 4). Anyway, it is plausible that the olfactory gland consists, as suggested by Toyoda (1960), of a short intraepithelial portion and an extraepithelial, main portion present in connective tissue layer, i.e., lamina propria and tela submucosa of olfactory mucosa.

A cross section of a supposed intraepithelial excretory duct of a bat olfactory gland is seen in Figure 13, in which three epithelial cells surround a common small luman. They protrude several short microvilli into the lumen and are connected by junctional complexes abutting on the luminal surface. Between lateral surfaces of the epithelial cells, fairly complex intercellular interdigitations are found. Along the basal surface facing the surrounding supporting cells of olfactory epithelium, weak basal infoldings are observed. These epithelial cells may probably be slender cells elongated in the apicobasal direction of the olfactory epithelium, and only in one cell situated on the right side of the central lumen, the nucleus is cut in the plane of the section. In the cytoplasm of these cells, besides several round and short mitochondria, abundant tubules of smooth endoplasmic reticulum are densely distributed in contrast to a small amount of flattened cisternae of rough endoplasmic reticulum scattering among the former. This finding in endoplasmic reticulum agrees with that observed in proper secretory cells of the olfactory gland as described below. Small Golgi complexes and dense bodies of variable sizes are also detected. One epithelial cell situated on the bottom left corner of the central lumen appears more electron dense than other cells, and contains a few secretory granules identical with those found in proper secretory cells of bat olfactory glands. In this respect, this epithelial cell agrees with that observed in Figure 4. Upon careful observation, it has been discerned that two other epithelial cells also possess a few minute secretory granules in their apical and supranuclear area, respectively (Fig. 13). These findings strongly suggest that the epithelial cells of this intraepithelial excretory duct may possess 


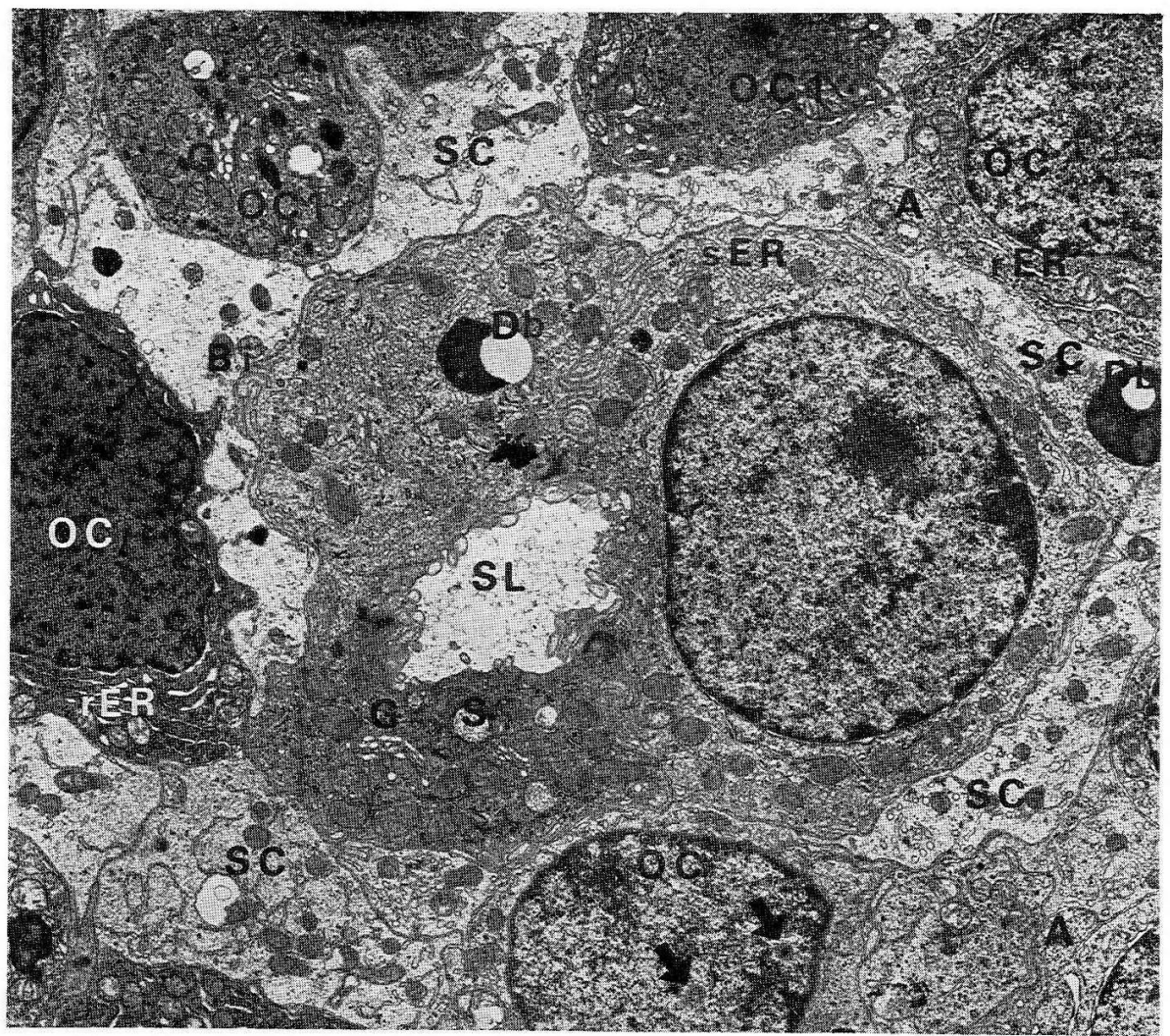

Fig. 13. Transverse section of probably intraepithelial excretory duct of a bat olfactory gland sectioned along a plane passing through perikaryons $(O C)$ of olfactory cells. A narrow duct lumen $(S L)$ is surrounded by 3 epithelial cells. Basal surfaces of epithelial cells facing supporting cells $(S C)$ are provided with basal infoldings $(B i)$; epithelial cells contain abundant sER, many mitochondria, Golgi complex $(G)$ and sparse secretory granules $(S)$ of low electron density. $A$ axon, $D b$ dense bodies, $O C I$ supranuclear parts of perikaryons, $r E R$ rough endoplasmic reticulum in perikaryons (Nissl substance). Arrows indicate spheridies (nuclear bodies) in the nucleus of an olfactory cells. $\times 8,000$

secretory activity to produce the same secretory product as proper secretory cells of the gland. If so, it may become unlikely that the olfactory gland of bat and rabbit might have a genuine excretory duct lacking in a secretory function.

Figure 14 shows a cross section of the intraepithelial secretory portion of a bat olfactory gland which has been cut in a plane presumably slightly shifted toward the basal surface of the olfactory epithelium from that in the cross section of Figure 13. The central glandular lumen is surrounded by numerous large cytoplasm-rich, conical or cuboidal secretory cells arranged almost radially, which contain variable amounts of electron-lucent secretory granules. Around this secretory portion, cross sections of olfactory epithelial cells are seen, but epithelial cells directly adjacent to the basal surfaces of secretory cells are almost exclusively supporting cells, which are characterized by containing tubular profiles of smooth endoplasmic reticulum and many dense bodies (lysosomes) of variable sizes. The basal surfaces of bat's 


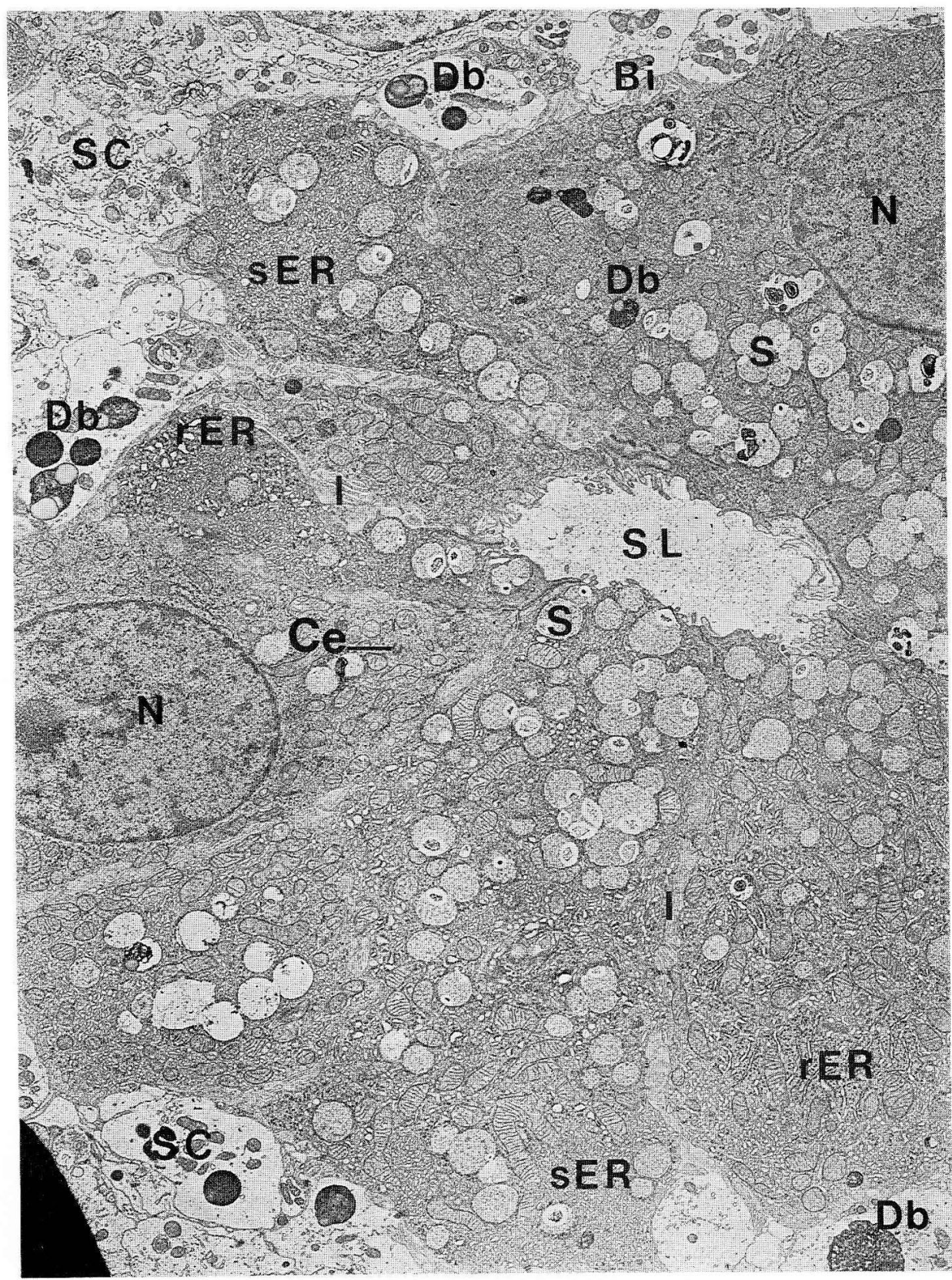

Fig. 14. Cross section of the intraepithelial secretory portion of a bat olfactory gland. The narrow central lumen $(S L)$ is surrounded by many large conical cytoplasm-rich secretory cells containing variable numbers of electron lucent secretory granules (S) with dense cores and numerous mitochondria. The cytoplasm of the secretory cells is filled with sER and rER. The basal surfaces of the secretory cells mostly facing supporting cells (SC) are provided with basal infoldings $(B i)$ and the lateral surfaces of adjacent secretory cells show intercellular interdigitations $(I)$. Supporting cells are distinguished by tubular profiles of sER and richness in dense bodies $(D h)$ probably lipofuscin granules. $C e$ centriole, $N$ nucleus of secretory cells. $\times 6,000$ 
secretory cells are provided, as mentioned above, with weak basal infoldings of the plasma membrane facing the supporting cells. Between these infoldings, parallel apposed plasma membranes of secretory and supporting cells are frequently connected by desmosomes (Fig. 14).

The neighboring secretory cells are connected with a junctional complex abutting on the luminal surface. The apposed lateral surfaces of the cells are provided with considerably well-developed intercellular interdigitations (Fig. 14). Desmosomes often occur in interrupted portions of the interdigitations, away from the junctional complex in the deeper portion between adjacent secretory cells (Fig. 14). The secretory cells protrude several short microvilli into the lumen.

Round nuclei of secretory cells are somewhat shifted toward the base of the cell. Chromatin distribution and the appearance of the nucleolus resemble those in the nuclei of supporting and olfactory cells. Considerably numerous rod-shaped and filamentous mitochondria are distributed throughout the cytoplasm being intermingled with secretory granules and extending along the long axis of the cell. They are somewhat larger than those of olfactory and supporting cells. Fairly welldeveloped Golgi complexes are found in the supranuclear area, and occasionally a centriole is detectable in the apical cytoplasm (Fig. 14). Electron dense bodies of variable shapes and sizes are observed in random areas of cytoplasm; they may probably be lysosomes or lipofuscin granules.

Secretory granules differ in amount from cell to cell. It is assumed, from the findings of the granules, that the secretory cells found in this cross section may be in various steps of a restitution stage, that is, they may be progressively elaborating the granules to store them in the cytoplasm. The elaborated secretory granules show a tendency to accumulate in the apical cytoplasm (Fig. 14). Secretory granules are bounded by a limiting membrane, and their matrix is electron-lucent and loosely fine-granular or flocculent, or occasionally loosely fine-fibrillar (Fig. 14); the texture of the matrix is thus more or less coarse. They frequently contain a small round, fairly electron dense core (Fig. 14). In the secretory cells shown in Figure 14, some secretory granules contain one or several highly electron dense cores, which exhibit a concentric lamellar structure similar to a myelin figure. As seen in Figure 14, coalescence of secretory granules is not rare.

The cytoplasm of secretory cells is filled with smooth and rough endoplasmic reticulum (Fig. 14). Components of smooth endoplasmic reticulum are larger in amount than those of rough endoplasmic reticulum, and the former are mainly tubular. They are diffusely distributed among mitochondria and secretory granules throughout the whole cytoplasm, but more or less conspicuous accumulations may occur in the basal as well as apical area and in random places of the cytoplasm (Fig. 14). The cisternae of rough endoplasmic reticulum are mostly of flattened and numerously attached ribosomes, usually accompanied by many free ribosomes, but in occasional sites or occasional cells, they may be more or less dilated (Fig. 14). In the areas where they are concentrated, they tend to form stacks of elongated parallel flattened sacs, exhibiting lamellar configurations (Fig. 14). The secretory cells resemble the supporting cells of the olfactory epithelium in predominance of the smooth endoplasmic reticulum components over the rough endoplasmic reticulum elements.

A number of authors have tried to classify secretory cells of the olfactory gland 


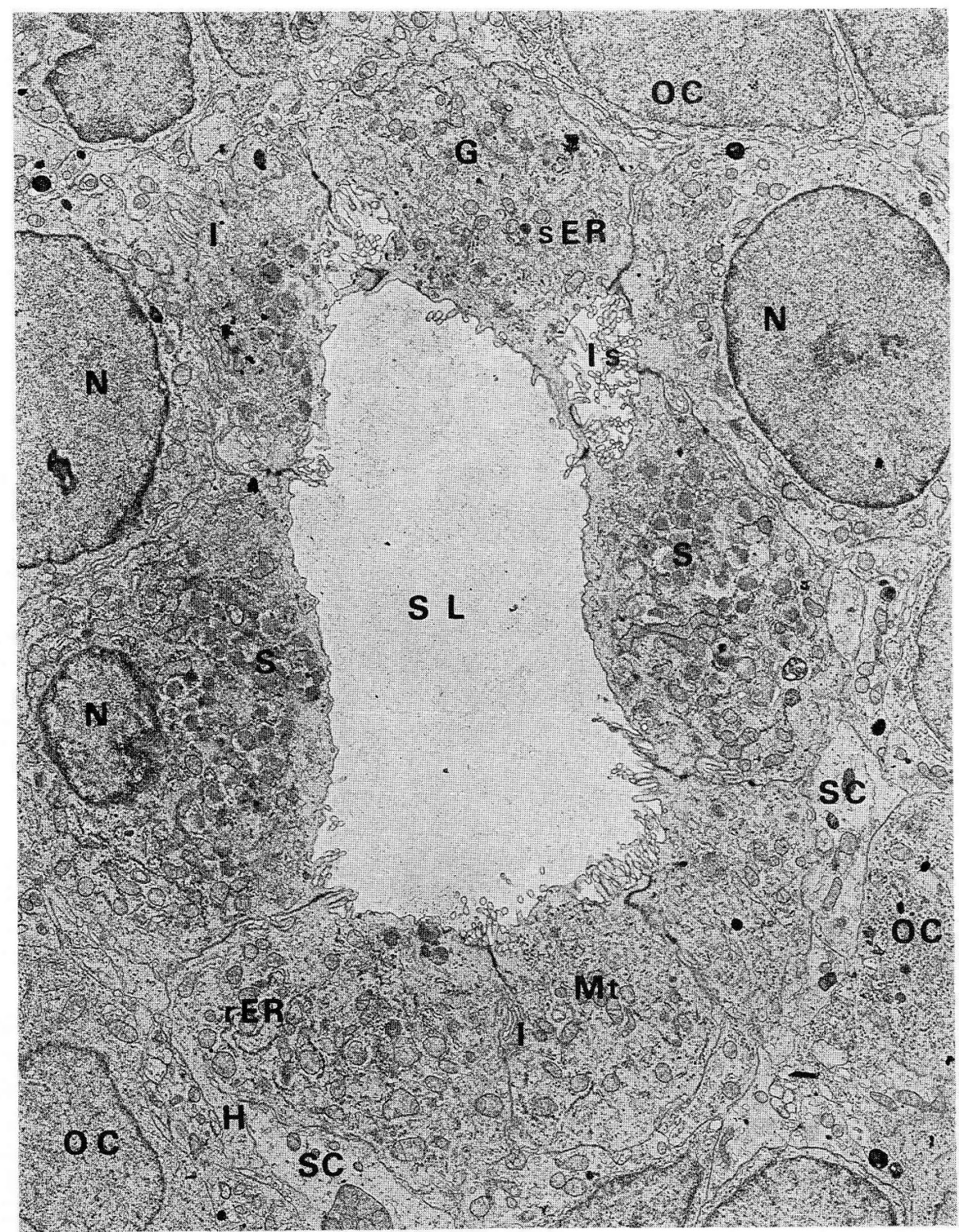

Fig. 15. Cross section of the intraepithelial secretory portion of a rabbit olfactory gland. The central lumen $(S L)$ is surrounded by numerous cuboidal secretory cells which contain numerous tubular elements of sER, small amounts of $\mathrm{rER}$ and variable numbers of secretory granules $(S)$ and mitochondria $(M t)$. The cell base facing supporting cells $(S C)$ occasionally protrude tongue-shaped processes $(H)$ : they contain no cell organelles except free ribosomes. $I$ intercellular interdigitation, $I s$ intercellular canaliculus characterized by abundant microvilli, $N$ nucleus of the secretory cells, $O C$ perikaryon of olfactory cell. $\quad \times 6,000$ 
into dark and light cells (Toyoda, 1960; Frisch, 1967; GraziadeI, 1972), but in the present study, the same attempt has been made almost in vain.

A cross section of the intraepithelial secretory portion of a rabbit olfactory gland is shown in Figure 15. Morphologically it resembles the corresponding portion of a bat olfactory gland, except for a few minute differences: A relatively wide central lumen is surrounded by a number of cuboidal cytoplasm-rich secretory cells arranged in a single layer. The amount of secretory granules contained in these secretory cells is different from cell to cell; some cells may even appear as if lacking in granules. Luminal surfaces of the cells protrude variable numbers of microvilli into the lumen, but cells containing large amounts of secretory granules possess a few or even none of the microvilli. Lateral surfaces of neighboring secretory cells exhibit weak interdigitations, and are connected by a junctional complex abutting on the luminal surface and by desmosomes in deeper portions (Fig. 15). Short intercellular canaliculi are occasionally found between the secretory cells, and their lumen is covered by numerous slender microvilli of the bordering cells. Findings of Golgi complex, mitochondria, lysosomes and nucleus are closely similar to those observed in the secretory cells of the intraepithelial secretory portion of the bat olfactory gland.

The secretory granules are bounded by a limiting membrane, and the electronlucent matrix appears fine granular or fine fibrillar. Two kinds of granules can be distinguished by the electron density of their matrix: fairly electron-dense granules showing a compact matrix texture and electron-lucent granules showing a loose matrix texture. Moreover, in both granules, a moderately electron dense round core is often distinct. These two kinds of secretory granules may probably represent two different stages of maturation. Coalescence of secretory granules is not uncommon.

The differentiation of the dark from light secretory cells according to their richness and poorness or lacking in the secretory granules seems to be erroneous.

As in the bat, the cytoplasm of rabbit intraepithelial grandular cells is densely packed with numerous tubules of smooth endoplasmic reticulum and less numerous flattened sacs of rough endoplasmic reticulum, accompanied by free ribosomes; the lamellar patterns produced by a parallel array of elongated flattened sacs of rough endoplasmic reticulum have not been found in rabbits.

Basal surfaces of rabbit intraepithelial secretory cells facing mainly the supporting cells of the surrounding olfactory epithelium are not provided with such basal infoldings as observed in the bat. Instead, unique bulkey tongue-shaped or bulbous cytoplasmic processes often are protruded between the basal surface of secretory cells and the surrounding supporting cells (Fig. 15). These cytoplasmic processes are bounded by a limiting membrane continuous with the basal plasma membrane of the secretory cell, and the homogeneously fine granular matrix of low electron density is also continuous with the cytoplasm of the latter, and it contains scarcely any cell organelles other than free ribosomes (polysomes) scattered throughout the entire matrix. As to these bulky cytoplasmic processes observed in rabbit intraepithelial secretory cells, further description will be given later.

A cross section of the extraepithelial secretory portion of a rabbit olfactory gland is shown in Figure 16. This extraepithelial secretory portion has been transversely cut in a plane passing through a deep layer of the lamina propria mucosae so as to 
show the main secretory portion of the olfactory gland. Along the basal surface of this portion facing the connective tissue, a basement membrane has hardly been demonstrated. Narrow glandular lumen is encircled by a number of secretory cells, which show cytological features similar to those observed in the intraepithelial secretory portion of the rabbit olfactory gland. The cells mostly contain more or less numerous secretory granules and are thought to be in various states of the restitution stage of the secretory cycle. Secretory granules mostly appear electron-lucent, and contain more or less electron dense cores; they show somewhat irregular contours, not rarely exhibiting coalescence. They tend to gather in apical cytoplasm, and as a consequence there appears a supranuclear area where numerous mitochondria together with Golgi complexes are accumulated, while secretory granules are almost lacking. Among these granulated cells in the restitution stage, there occur a few cells apparently lacking in secretory granules (secretory cells in the empty stage).

The cytoplasm of the secretory cells of the extraepithelial secretory portion of

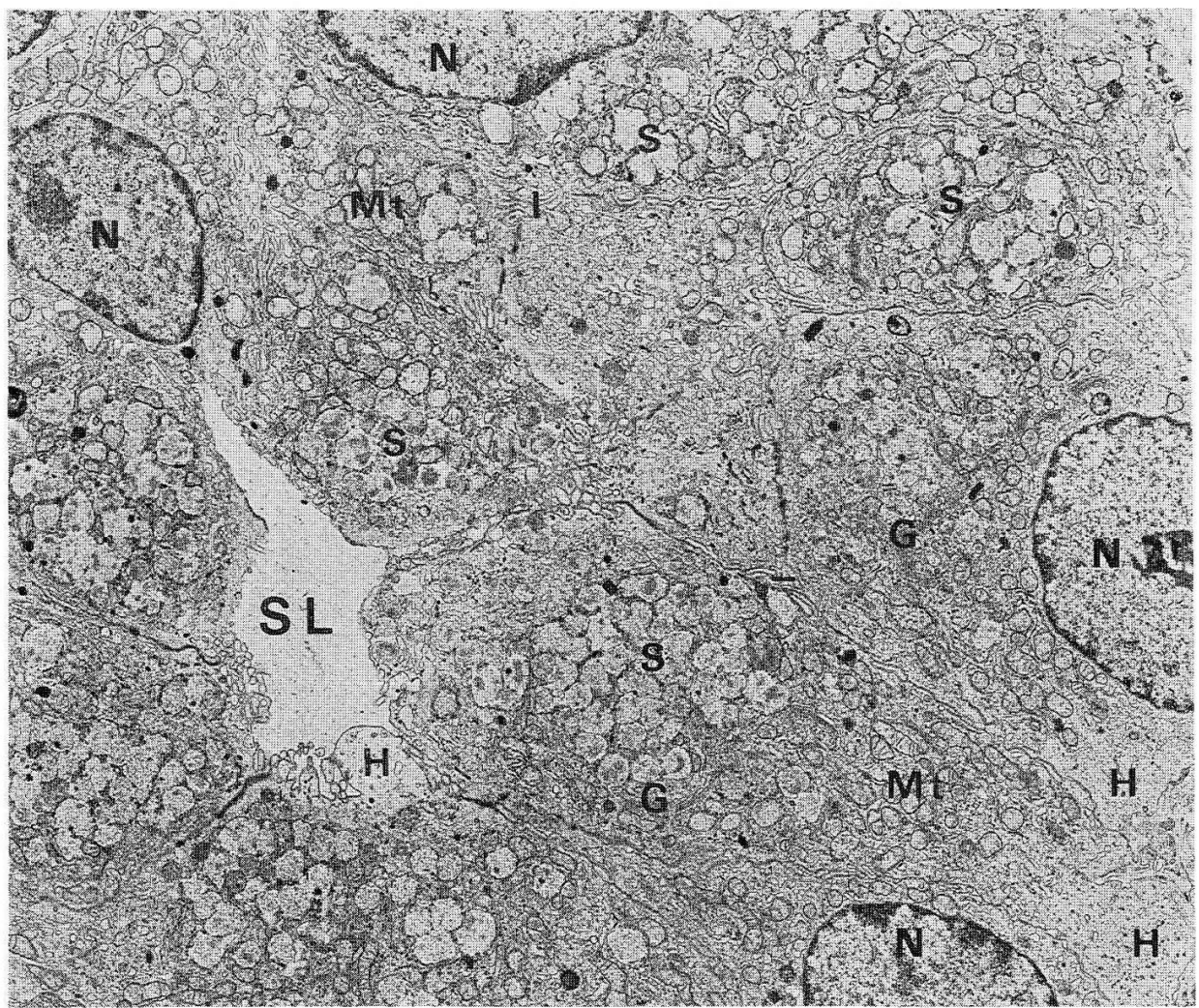

Fig. 16. Cross section of the extraepithelial secretory portion of a rabbit olfactory gland (somewhat obliquely sectioned). Many secretory cells surrounding glandular lumen (SL) contain for the most part numerous secretory granules $(S)$, showing electron dense cores. Tubular components of sER are not well-defined. From the cell base bulky tongue-shaped processes $(H)$ are protruded into the connective tissue. They contain no cell organelles except free ribosomes. A similar tongueshaped, electron-lucent process $(H)$ is projected from the cell apex into the glandular lumen. $G$ Golgi complex, $I$ intercellular interdigitation, $M t$ mitochondria, $N$ nuclei of secretory cells. $\times 6,000$ 
the rabbit olfactory gland is entirely filled with tubular components of smooth endoplasmic reticulum and less numerous elements of rough endoplasmic reticulum and associated free ribosomes (Fig. 16). Bulky bulbous or tongue-shaped cytoplasmic processes of low electron density occur here also, and they are projected not only from the cell base into surrounding connective tissue but also from the apex into the glandular lumen (Fig. 16).

Secretory cells from the extraepithelial secretory portion of the rabbit olfactory gland are shown in Figure 17 at somewhat higher magnification. The cytoplasm of

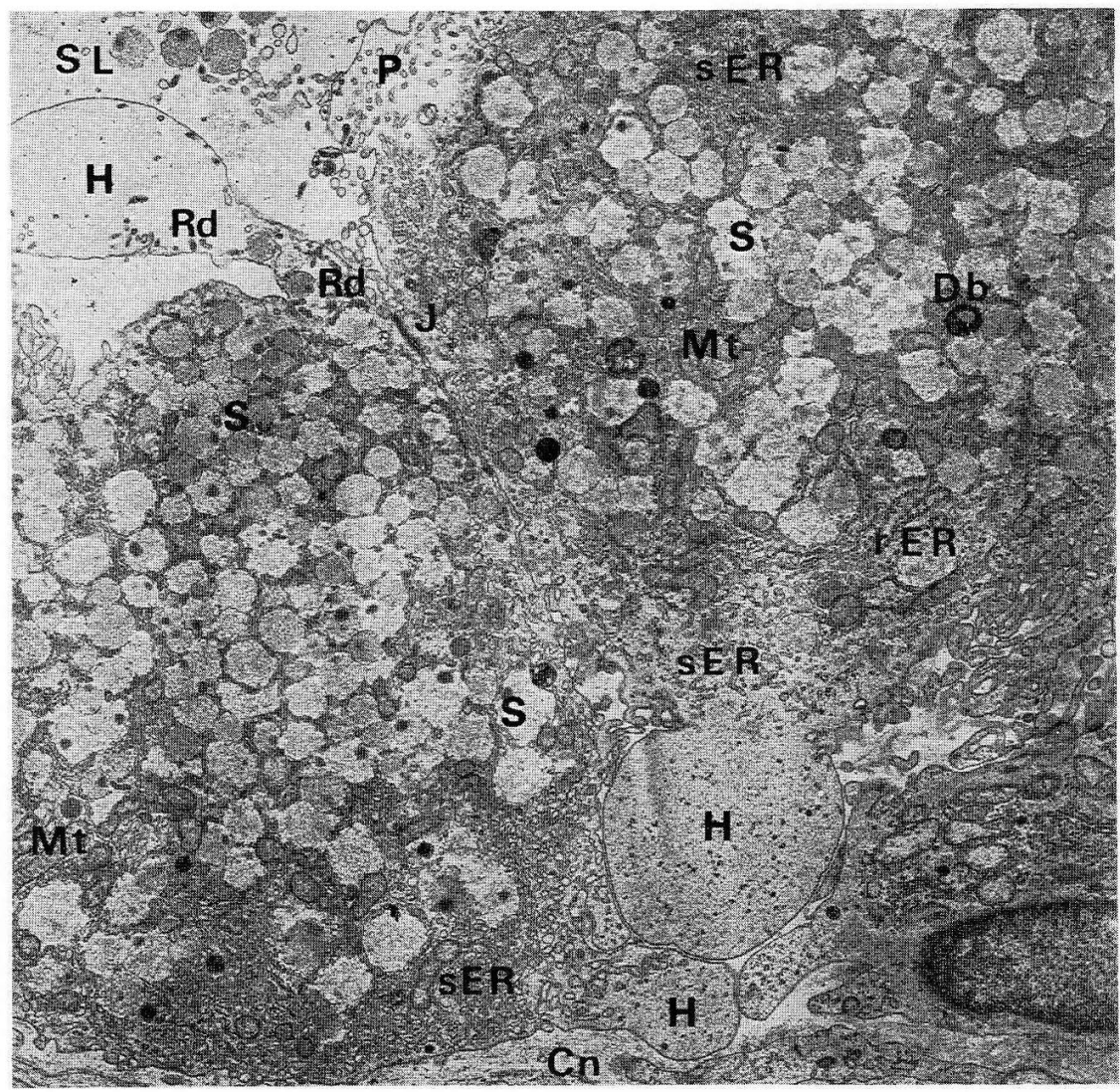

Fig. 17. Two secretory cells from the extraepithelial secretory portion of a rabbit olfactory gland. Note abundant secretory granules $(S)$ and densely packed tubular components of SER in between. Secretory granules contain distinct electron dense cores. From the cell base tongue-shaped electron lucent processes $(H)$ are sent out into connective tissue $(C n)$ which contain no cell organelles except ribosomes. From the cell apex on the left side a similar clear, tongue-shaped process protrudes into glandular lumen (SL) which contains, besides ribosomes, dense rodlets $(R d)$. The secretory cell apex on the right side forms a wide protuberance $(P)$ bulging into the lumen which contains tubular components of the sER and dense rodlets, the latter being found also in the apical areas of the cell among the secretory granules. No distinct basement membrane is identified. In the glandular lumen artificially extruded secretory granules and components of the sER are seen. $D b$ dense body, $J$ junctional complex, $M t$ mitochondria. $\quad \times 8,000$ 
the secretory cells is filled with abundant densely distributed secretory granules so that they are thought to be in the repletion stage of the secretory cycle. Secretory granules bounded by limiting membrane possess finely granular or fibrillar matrix and, as described above, are classified into fairly dense and less dense ones according to the matrix texture. Between the two types of granules, there are intermediate or transitional forms. All these forms partially contain a more or less dense single round core situated mostly eccentrically. In general, moderately dense secretory granules show small and round profiles, while less dense ones are large and possess more or less irregular and wavy contours. These morphological differences probably suggest that the moderately dense granules may represent the younger or immature and the less dense ones mature secretory granules. In the latter, the limiting membrane frequently appears fragmented and closely adjacent granules are often in coalescence. Upon careful observation, it is readily confirmed that in the narrow cytoplasm separating the closely distributed secretory granules, densely packed tubules of smooth endoplasmic reticulum intervene, while other organelles such as mitochondria and elongated cisternae of rough endoplasmic reticulum as well as free ribosomes are for the most part driven away into the lateral and basal area of the cell, where distribution of both secretory granules and tubular components of smooth endoplasmic reticulum becomes gradually scarce. In the apical zone of the secretory cell subjacent to the luminal surface, the distribution of tubular components of smooth endoplasmic reticulum is also unevenly scarce.

Dense bodies (probably lysosomes or lipofuscin granules) of variable sizes are scattered at random, and some of them exhibit a complicated internal structure.

Moderately dense secretory granules and tubular components of smooth endoplasmic reticulum in glandular lumen (Fig. 17) are considered to be artifacts, i.e., organelles artificially extruded into the lumen.

Basal surfaces of both secretory cells existing on the left and right side of Figure 17 protrude similar bulky bulbous or tongue-shaped cytoplasmic processes to those descrived above. These basal processes projected into the connective tissue are homogeneously fine granular and are bounded by the plasma membrane continuous with that bordering the basal surfaces of the secretory cells. They merely contain scattered polysomes and scanty small vesicles in the matrix. Arrangement of densely packed tubular elements of smooth endoplasmic reticulum in the cell body becomes more loosened toward constricted necks of the processes to disappear gradually before entering, beyond the neck, the interior of the processes (Fig. 17).

From the apical cytoplasm of the secretory cell, a long club- or tongue-shaped process is protruded into the glandular lumen. Its end part expands into a bulbous swelling, and the neck is greatly constricted. The plasma membrane of the secretory cell extends to bind this process continuously. The almost electron-transparent matrix is homogeneously fine granular or fine fibrillar and contains scanty polysomes and several small vesicles as well as electron dense rodlets, being mainly distributed along the limiting membrane. The constricted neck of the process contains, in the matrix, a few small secretory granules and a number of dense rodlets, so that the matrix resembles the apical cytoplasm, which contains these two structures in a considerable number. Structures called "dense rodlets" may be referred to as fragments of tubular components of smooth endoplasmic reticulum containing a dense material. They are 
bounded by a limiting membrane, and are thought to have been produced by pinchingoff or fragmentation of the tubules containing a dense matcrial probably elaborated within the smooth endoplasmic reticulum (Fig. 19). The identical structures are also detectable in considerable number among secretory granules in cytoplasmic areas

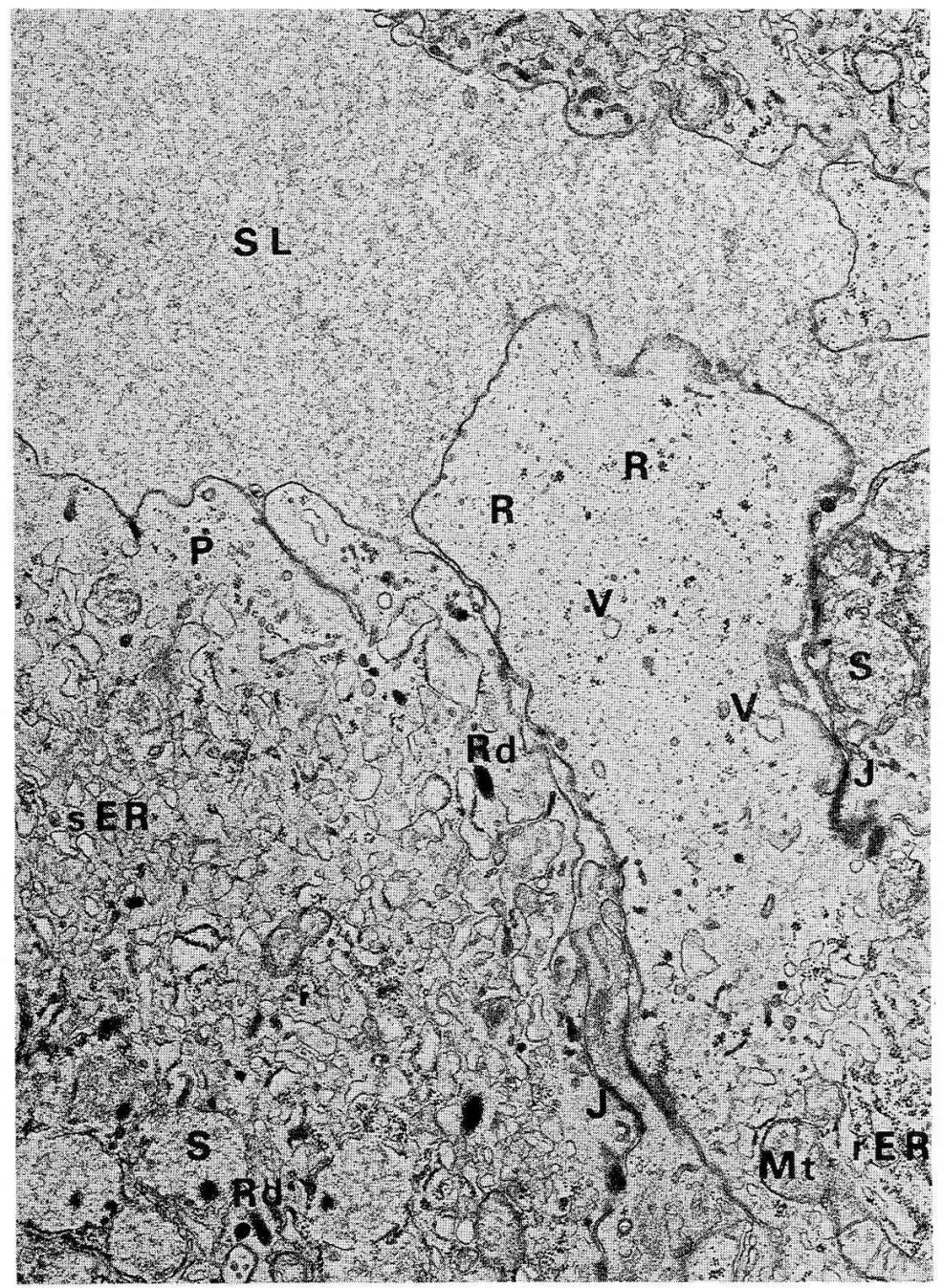

Fig. 18. Apical tongue-shaped process of a secretory cell protruded into the glandular lumen $(S L)$ of the extraepithelial secretory portion of a rabbit olfactory gland. The electron-lucent matrix of this process contains merely scattering ribosomes and small smooth vesicles. The cytoplasm of the secretory cell on the left side is filled with numerous components of sER and less numerous components of $\mathrm{rER}$ and sends out a wide clear protuberance $(P)$ whose matrix resembles that of the tongue-shaped process on the right side. $J$ junctional complex, $M t$ mitochondria, $R d$ dense rodlets, $S$ secretory granules with fragmented limiting membranes. $\times 16,000$ 


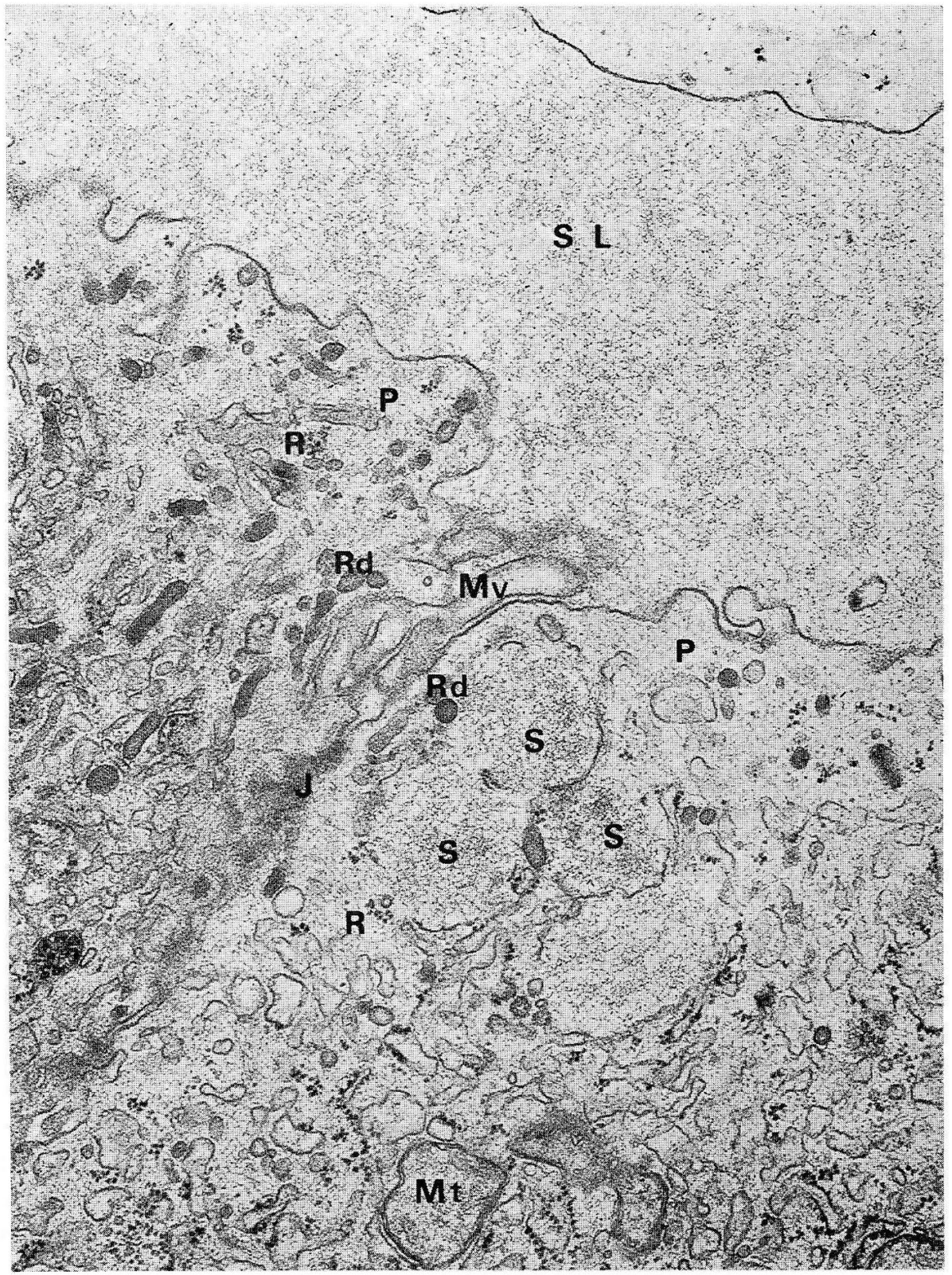

Fig. 19. Wide protuberances $(P)$ bulging into the glandular lumen (SL) of two adjacent secretory cells. The electron-lucent matrix of the protuberances contains scattering ribosomes (polysomes) $(R)$, loosely arranged tubular elements of sER and smooth membrane-bound dense rodlets $(R d)$ which have presumably been derived from the tubular components of sER. In the protuberance on the right side 4 secretory granules $(S)$ are seen whose limiting membranes are fragmented and the granule substance apparently is flowing out into the cytoplasm. Note the fine structural resemblance of the granule substance and the matrix of the protuberances. $J$ junctional complex, $M t$ mitochondrion, $M v$ microvilli. $\times 33,000$ 
nearer to the apical end of the cell. The dense rodlets may probably have been transferred through the neck into the process, which resembles, in external appearance, the apocrine process of apocrine glands found elsewhere. Separation by pinching-off of this process into the glandular lumen seems very likely to occur.

Luminal surface of the secretory cell on the right side of Figure 17 bulges into the lumen making a wide protuberance filled with an electron-transparent matrix or cytoplasm, in which tubular components of smooth endoplasmic reticulum are loosely distributed; among them electron dense rodlets are also demonstrated. Such an electron-lucent protuberance is thought to be a cytoplasmic structure of the same origin and nature with the bulky processes described above, and is not rarely observed in secretory cells of the rabbit olfactory gland.

In Figure 18, a tongue-shaped cytoplasmic process is shown, protruding from the apical end of a secretory cell into the glandular lumen. Its slightly constricted neck is connected by junctional complexes with neighboring secretory cells. The limiting membrane is distinct, and polysomes and scanty vesicles are scattered in the electron-lucent matrix.

Figure 19 shows two wide protuberances bulging into the glandular lumen from luminal surfaces of two adjacent secretory cells. Free surfaces facing the glandular lumen are almost lacking in microvilli except the short lateral surfaces reflected toward the junctional complex, where many long microvilli are preserved. In the electron-lucent matrix or cytoplasm, free polysomes and electron dense rodlets are randomly scattered besides tubular elements of smooth endoplasmic reticulum, and in the protuberance on the right side, four secretory granules are present just beneath the plasma membrane limiting the protuberance. In these secretory granules, limiting membranes are fragmented, and through these discontinuities, their contents have flowed into the surrounding cytoplasm or matrix of the protuberance; fine granular or fibrillar contents of the secretory granules seem to invade the matrix and they seem to contribute principally to the formation of the protuberance. The content of secretory granules and the matrix of the protuberance are similar to each other in ultrastructural appearance, and they further resemble the secretion material within the glandular lumen.

As described above, secretory granules usually tend to accumulate in the apical area of the secretory cell, and some of them are often found just beneath plasma membrane lining the apical or luminal surface (Fig. 14, 15, 18). However, figures suggestive of the discharge of secretory granules by means of emiocytotic mechanism have scarcely been confirmed in spite of careful observation. Furthermore, two mechanisms of discharge of secretion material other than emiocytosis may be expected especially in the rabbit olfactory gland; they are the diacrine and apocrine mechanism. Cytological findings in favor of diacrine mechanism are as follows: Contents of secretory granules, as described above, permeate through the fragmented limiting membrane into the apical cytoplasm and may be discharged into the glandular lumen by diffusion through the apical plasma membrane. The contents of secretory granules and secretion material within the glandular lumen appear closely alike. The permeation of secretory granule content into cytoplasm can not be confined to the apical area of secretory cells, since fragmentation of the limiting membrane of secretory granules is observed at random areas of secretory cells. Permeated secretory material may 
perhaps flow toward the apical area. The apocrine mechanism is supported by the frequent occurrence of bulky tongue-shaped processes protruded into the glandular lumen, which however, do not contain secretory granules. The mode of formation of the tongue-shaped process may be explained as follows: Contents of secretory granules filtrate the cytoplasm and make at first a protuberance toward the glandular lumen, which then is projected far into the lumen probably in consequence of further increase of material from secretory granules infiltrating the cytoplasm.

Similar basal processes projected into the surrounding olfactory epithelium or connective tissue may be formed probably by the same mechanism as in the case of apical processes. The fate and significance of basal tongue-shaped processes are unknown in constrast to the apical ones, which are thought to be pinched off into glandular lumen by an apocrine process. Electron-lucent homogeneously fine granular or fibrillar matrices of both apical and basal processes are almost identical, containing considerable amounts of polysomes and scanty smooth vesicles as shown in Figures

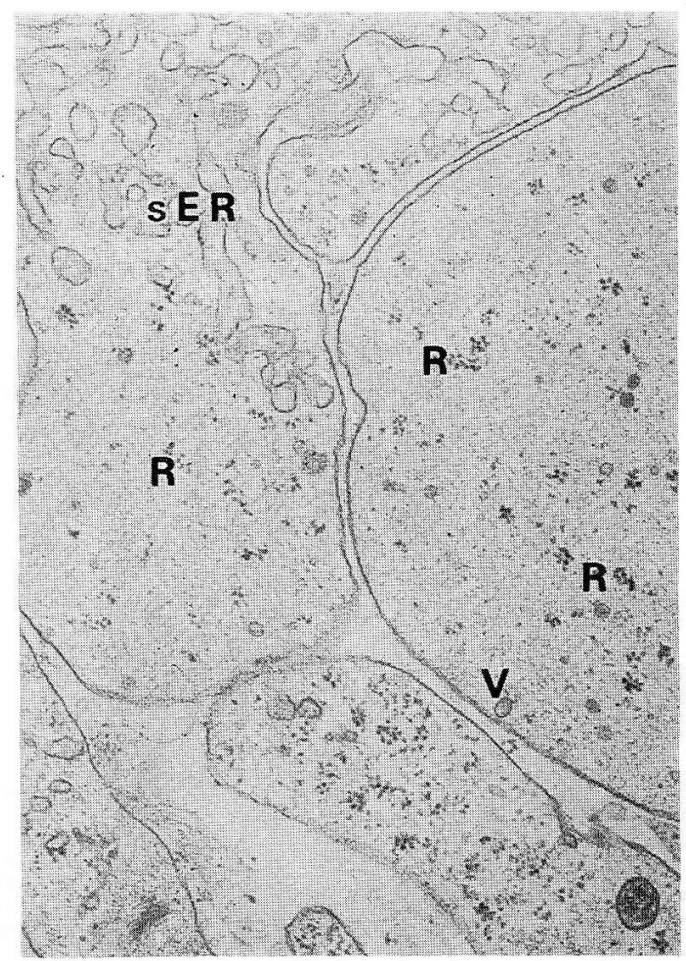

Fig. 20. Basal tongue-shaped processes of secretory cells protruded toward the connective tissue. They are bounded by a limiting membrane continuous with the plasma membrane of the cell base and their matrix of low electron density contains merely free ribosomes $(R)$ (polysomes) and small smooth vesicles $(V)$. Components of sER disappear at the neck of the process and so-called dense rodlets can not be found in the basal processes. $\times 27,000$

16, 17 and 20. The only difference between both processes consists in that the former contains, besides polysomes and vesicles, the so-called dense rodlets as mentioned above, which are completely lacking in the latter.

The relation between Golgi complex and the formation of secretory granules has been examined in the bat (Fig. 21) and rabbit olfactory gland (Fig. 22), and in both animals similar findings have been obtained.

In both species several Golgi complexes of secretory cells are distributed in supraand paranuclear regions of cytoplasm. Each Golgi complex consists of a stack of 4-5 short flattened cisternae closely arranged in parallel (Golgi lamellae) and many vesicles distributed around the lamellae. Vacuoles of variable sizes are observed in a small number in the Golgi area. Vesicles attaching to flattened sacs of the Golgi lamellae are frequently observed (Fig. 21, 22). This suggests the possibility that vesicles, probably derived from components of smooth and/or rough endoplasmic reticulum, may transfer secretory substances produced in them together with membranes to the 
Golgi complex (transfer vesicles). In both species, among Golgi vesicles, a considerable number of so-called coated vesicles are detected (Fig. 21, 22), being often attached to one end of the Golgi cisternae. Moreover, along the lateral and basal cell surfaces, coated invaginations of plasma membrane and coated pinocytotic vesicles are occasionally observed, and this together with the above evidence suggests that certain substances (probably macromolecules) may be ingested by micropinocytosis from the extracellular space into the cytoplasm and transferred by coated vesicles to the Golgi complex. Golgi vacuoles are thought to originate from expanded portions of Golgi

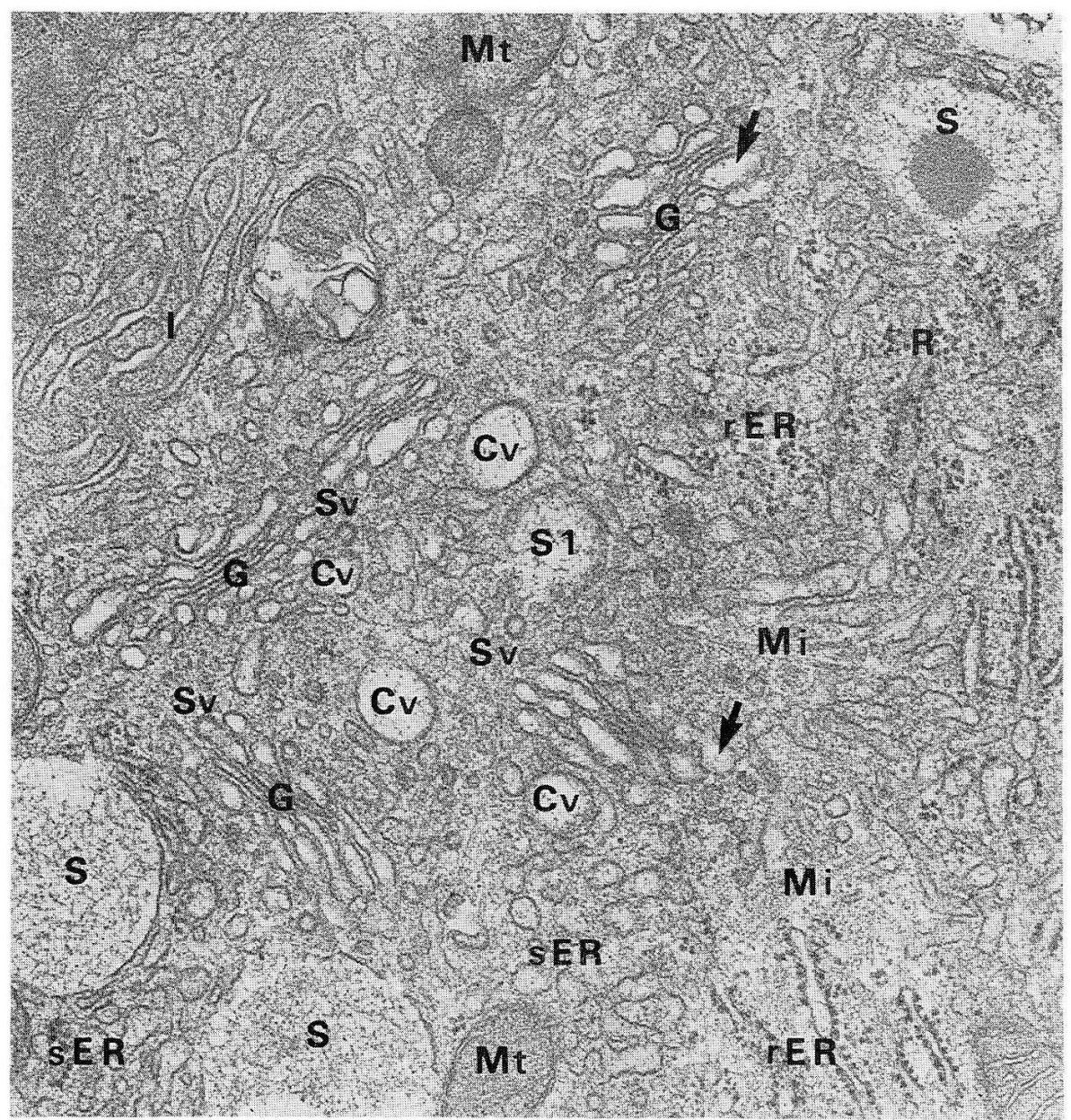

Fig. 21. Golgi complexes $(G)$ in the vicinty of the nucleus of a secretory cell from the extraepithelial secretory portion of a bat olfactory gland. Golgi complexes are composed of stacks of 4-5 short flattened cisternae, a small number of vacuoles (condensing vacuoles) (Cv) and many small vesicles among which several larger coated vesicles $(S v)$ are intermingled. In flattened Golgi cisternae expanded portions (arrows) are frequently observed from which may arise Golgi vacuoles (condensing vacuoles). The latter will be transformed into small immature secretory granules $\left(S_{1}\right)$. Golgi vesicles and coated vesicles are found frequently adhering to one end of the Golgi cisternae. I intercellular interdigitation, $M i$ microtubules, $M t$ mitochondria, $R$ ribosomes, $S$ secretory granules. $\times 35,000$ 
cisternae, which are frequently encountered in Golgi complexes of both bat and rabbit olfactory glandular cells, and they contain, like expanded portions of the Golgi cisternae, a small amount of a fine fibrillar material (Fig. 21, 22). Concomitant with the growth of the vacuole, the fibrillar material increases in amount, and appears more condensed (condensing vacuole). Assumedly these condensing vacuoles may gradually turn into small immature secretory granules as the consequence of growth and increase of the content (Fig. 21, 22). The condensing vacuoles and the small immature secretory granules are found side by side near Golgi complexes, and distinction between them is often difficult.

On the basis of the above findings, it can be concluded that secretory granules of

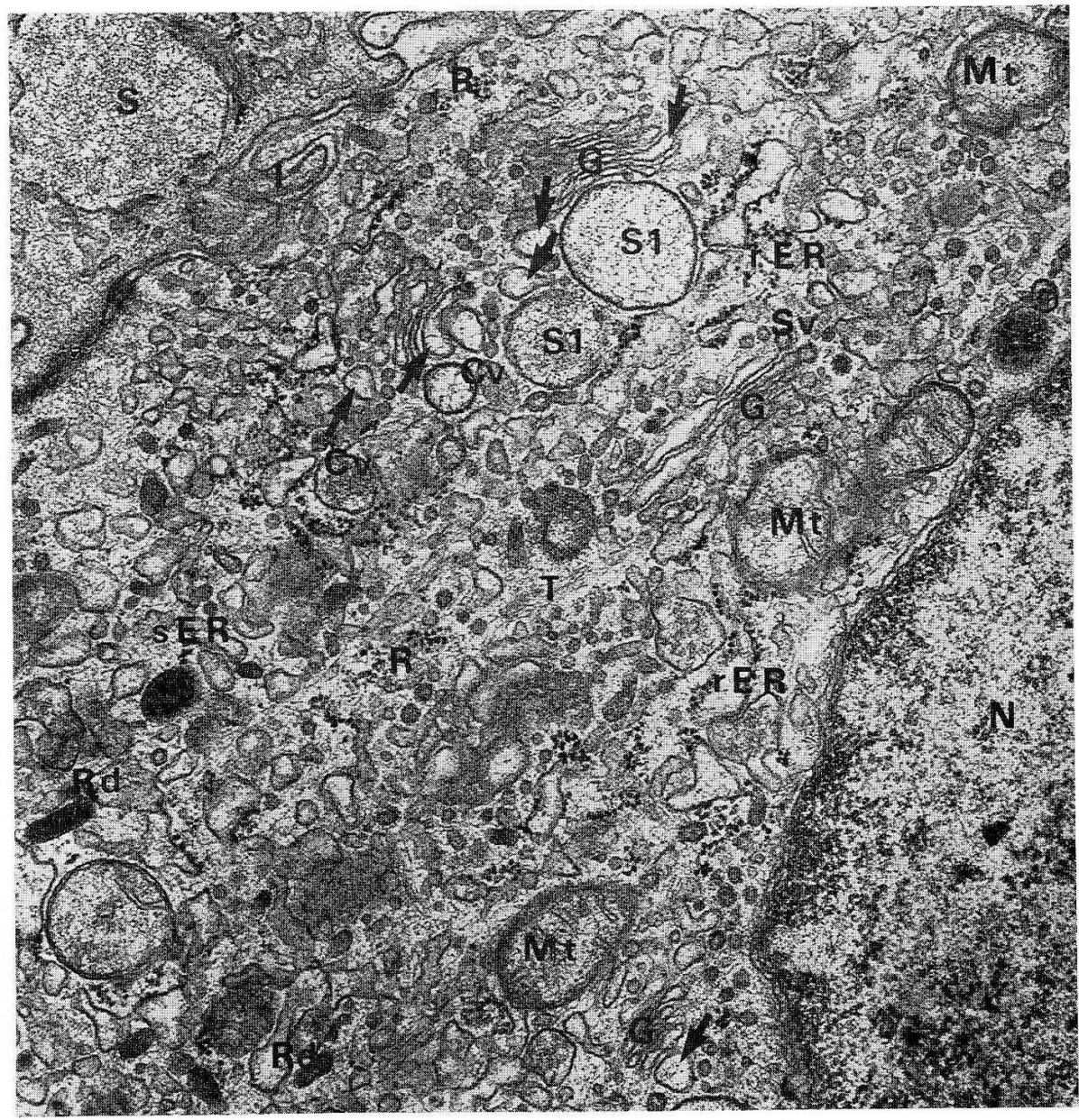

Fig. 22. Golgi complexes $(G)$ in the vicinity of the nucleus $(N)$ of a sccretory cell from the extraepithelial secretory portion of a rabbit olfactory gland. For explanation see the legend for Figure 21. Cv Golgi vacuoles (condensing vacuoles), $I$ intercellular interdigitation, $M t$ mitochondria, $R$ ribosomes, $R d$ dense rodlets, $S$ secretory granule, $S 1$ small immature secretory granules, $S v$ coated vesicles, $T$ tonofilaments. Arrows indicate expanded portions of the Golgi cisternae and their transitional stages to the Golgi vacuoles. $\times 34,000$ 
olfactory glandular cells must be formed in the Golgi complex, that it secretory materials transferred by vesicles to the Golgi complex are packaged by the Golgi membrane into membrane-bound secretory granules. But the question of the production site of the secretory material can not be answered, in spite of strong probabilities that smooth endoplasmic reticulum or rough endoplasmic reticulum or both of them may be responsible.

Nor has it ultimately been decided whether olfactory gland may be serous or mucous, although Toyoda (1960) has claimed that in many examined mammalian species it was proved to be mucous. In this study, the olfactory gland in bat and rabbit olfactory mucosa has been histochemically examined; thick sections of Eponembedded specimens were stained with toluidine blue for light microscopy, and it was revealed that secretory granules accumulated in the luminal cytoplasm of olfactory glandular cells were metachromatically stained reddish-purple. Further specimens were fixed in 10\% formalin or Zenker-formalin and paraffin sections were treated with PAS, Bauer's method and alcian blue for mucus staining. In these mucus stainings, secretory granules in olfactory grandular cells and the mucous film covering the olfactory epithelium both reacted positively. As observed in the electron microscope, secretory granules in the bat and rabbit olfactory gland are very similar to each other in their fine structural findings; their matrix is alike of low electron density consisting of fine fibrillar or granular material loosely distributed in the matrix so that it shows a relatively coarse texture. It frequently contains, in the interior, a moderately dense core with a roughly round profile. These histochemical and fine structural characteristics of secretory granules may probably offer reliable and powerful evidence for the solution of the problem whether the olfactory gland should belong to the mucous or serous type, and indeed in favor of the former. Finally, the ruthenium red staining test, devised and recommended by LuFT (1971) for mucus staining, has been applied in this study to the secretory portion of the bat olfactory gland, and a positive result was obtained. Thus ruthenium red stainable secretory material discharged from secretory cells was electron-microscopically demonstrated in glandular lumen of the olfactory gland (Fig. 23).

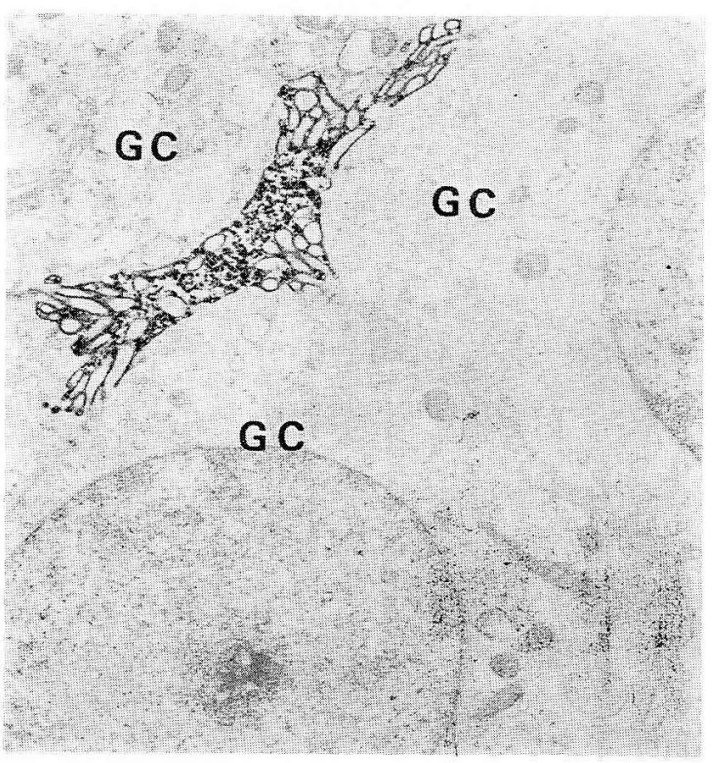

Fig. 23. Ruthenium red staining](LuFT, 1971) iof bat olfactory gland. Secretion material in glandular lumen shows a positive reaction. Microvilli of secretory cells $(G C)$ appear as electron lucent, finger-shaped processes within positively reacted electron dense secretion material. $\times 8,300$

In this study, olfactory mucosae of wild bats, Rhinolophus ferrum equinum nippon and of domestic albino rabbits have been electron microscopically 
investigated. The olfactory mucosae including olfactory epithelium and olfactory gland of these mammalian species, especially of the bat have remained scarcely studied with the electron microscope. In bat and rabbit olfactory epithelium, 4 cell types have been classified: olfactory cell, supporting cell, basal cell and interstitial or intercalated cell, the last being the newly identified cell type in the present study. The following paragraphs will discuss one by one these cell types together with the olfactory gland. Olfactory epithelium represents, as widely accepted (GRAZIADEI, 1972), a typical pseudostratified columnar epithelium; main component cells-supporting and olfactory cells - are tall columnar, and their lateral surfaces are apposed parallel, being separated by a narrow intercellular space about $200 \AA$ across; and lining plasma membranes do not make any intercellular interdigitations, but intercellular space becomes wider and complicated in the basal part between foot processes of supporting cells and basal cells. Adjacent supporting cells themselves, or these and olfactory cells or, occasionally adjacent olfactory cells themselves are connected by a junctional complex abutting on the free surface of the olfactory epithelium, but desmosomes can additionally appear at random places away from junctional complexes throughout the entire height of the epithelium. The foot process of the supporting cell as well as the basal surface of the basal cell are connected by means of many hemidesmosomes to the basement membrane of the olfactory epithelium. These junctional specializations have remained for a long time without receiving any special attention of investigators, although they have been wellknown in the dermoepidermal junction and the junction between stratified squamous epithelium of the esophagus and underlying lamina propria mucosae (Iто and IsHII, 1970).

The so-called mucous film or layer about $10-40 \mu$ thick (GRAZIADEI, 1972) covering the free surface of olfactory epithelium has been described by almost all authors who have dealt with the olfactory epithelium, and some authors divided it into 3 layers (ANDREs, 1969). It contains all structures protruded from olfactory cells and supporting cells, namely, olfactory vesicles, olfactory cilia and abundant microvilli are embedded in the substance of the mucous film, constituting a complex meshwork. Chemical substances which stimulate olfactory epithelium to establish olfactory sense must be dissolved and permeate first into this mucous film. In bats and rabbits, as in other mammalian species, secretory substance discharged from olfactory glands may participate mainly in the formation of the mucous film.

\section{Supporting cell}

Presence of complicated and irregularly-shaped long microvilli protruding into the mucous film is one of the important morphological characteristics of supporting cells of mammalian species, although, according to the review of GRAZIADEI (1972), their development and morphological features vary depending on animal species and functional conditions. Both bat and rabbit supporting cells bear numerous slender irregularly-shaped, partially branched microvilli of considerable length, extending into mucous film, and light microscopically observed as brush border. In electron microscopic study on olfactory epithelium, no authors except ANDREs (1969) have discussed whether microvilli of the supporting cell are provided with axial filaments or not. The present author, however, has proved their complete absence in bat and rabbit in agreement with ANDREs. 
One of the important findings in the present study concerns the unique and delicate bubble-like or polypoid or drumstick-shaped processes which are protruded from the outer leaflet of the plasma membrane bounding the microvilli and free surface of supporting cells. These delicate processes are constricted at their basal part, while the apical ends form a vesicular swelling, measuring approximately $300 \AA$ in diameter. They are limited by a very thin membrane quite different from plasma membrane with trilaminal structure. In both bat and rabbit, these fine processes have been reveald in a great number along the free surface of supporting cells including microvilli, though somewhat less in rabbits. These unique processes have not been noticed by any investigators engaged in the electron microscopic studies of the olfactory epithelium. Recently KRATZING (1972) has observed similar fine processes which are protruded from the plasma membrane, limiting the basal part of olfactory cilia and adjacent elevated areas, which have been induced by underlying basal bodies. These numerous fine processes, protruding from the restricted portion of olfactory vesicle, were called by her "setulae or bristles"; they measured, according to her, about $200 \AA$ in length, and were arranged in 9 rows coinciding with the 9 peripheral tubules of the basal body and cilium. She could reveal, however, no comparable structures on the surface of supporting cells or their microvilli. Concerning the functional significance of these fine processes, she described that the additional area of cell membrane obtained in each cilium by the presence of many fine extensions around the cilium base would add significantly to the surface of the receptor cell and thus to the sites available for contact with odorous substances. It can readily be expected that delicate bubble-like processes found in the surface of supporting cells and their microvilli might contribute also to the extension of the surface area of supporting cells which facing the mucous film. On the other hand, however, it can be presumed that they may possibly indicate the discharge of some unknown substance into the mucous film by a mechanism like the microapocrine process proposed by Kurosumi (1961), because bubble-like processes are supposed to be liberated by pinching off at the constricted basal portion into the mucous film.

The second conspicuous cytological feature of bat and rabbit supporting cells is the richness in smooth endoplasmic reticulum; tubular components of the reticulum are distributed throughout the entire cytoplasm, but especially in supranuclear and apical cytoplasm beneath the terminal web, abundant tubular profiles are aligned mainly along the lateral surface of the cell, making dense parallel arrays of considerable thickness; in the central area, they are arranged chiefly in a loose network. In contrast to the richness in smooth endoplasmic reticulum, organized elements of rough endoplasmic reticulum and free ribosomes are not so numerous in either bat or rabbit supporting cells. The richness in smooth and rough endoplasmic reticula in supporting cells has been noticed by authors who have been engaged in the electron microscopic study of olfactory epithelium (FrISCH, 1967; GRAZIADEI, 1972 etc.) with or without regard to the secretory function of supporting cells.

On the basis of cytological evidence obtained by several authors, it can be concluded that in lower vertebrates, the supporting cell has a secretory function (BLoom, 1954 in toad and frog; Porter and Bonneville, 1964 in toad; Bronshtein and Ivanov, 1965 in lamprey; ReESE, 1965 in frog; Wesolowski, 1967 in turkey; GrazIAdeI, 1972 in box turtle; OKano and Takagi, 1974 in bullfrog etc.). In mammalian species, the 
secretory function of supporting cells has not generally been confirmed by any investigators except FrISCH (1967), who electron microscopically studied the olfactory epithelium and Bowman's gland in mouse, thus revealing the presence of a few secretory granules in supporting cells. In these cells, he observed stacked membranes of smooth endoplasmic reticulum.

In this study, any cytological findings indicating the secretory activity of supporting cells have never been demonstrated either in bat or rabbit supporting cells. In spite of the richness in smooth endoplasmic reticulum and considerable amounts of organized elements of rough endoplasmic reticulum cytological signs of production of secretory granules have completely been missed; also in supranuclear Golgi complexes, sequences of formation of secretory granules have not been confirmed.

Besides the endoplasmic reticulum, free ribosomes and Golgi complexes, other cell organelles such as mitochondria, centriole, multivesicular bodies, microtubules, tonofilaments and dense bodies (probably lysosomes) have been revealed in supporting cells of both bat and rabbit. Especially many mitochondria are concentrated in apical and supranuclear regions, and they are surrounded by basket-like configurations of tubular profiles of smooth endoplasmic reticulum, as pointed out by FRISCH (1967) in mouse supporting cells.

FRISCH (1967) demonstrated, in both supporting cells and dark secretory cells of mouse Bowman's gland, "whorl system" composed of concentrically arranged membranes of smooth endoplasmic reticulum. In bat and rabbit supporting cells, these whorl-like lamellar configurations have been observed both in supra- and infranuclear areas, while in secretory cells of the olfactory gland of both species, which are alike rich in tubular elements of smooth endoplasmic reticulum, and, which, in contrast to the supporting cell, are provided with an intensive secretory activity as discussed below, these whorl-like organizations of smooth membranes have not been demonstrated. From these findings it has been supposed that in secretory inactive supporting cells of bat and rabbit olfactory epithelium, abundant components of smooth endoplasmic reticulum may have become unnecessary, consequently turning into whorl systems in restricted areas. Concerning phylogenetic alteration of the supporting cell, it can reasonably be assumed that in vertebrates, these cells may have initially carried out a secretory function under participation of the endoplasmic reticulum, especially of the smooth one, but that with advance in the development, the secretory function may have disappeared on account of unknown reasons, leaving abundant components of the endoplasmic reticulum without any functional roles.

Bat and rabbit supporting cells are further characterized by the presence of considerably numerous dense bodies of variable sizes__assumedly lysosomes. In both vertebrate species, they are more numerous in supporting cells than in olfactory, basal and secretory cells of the olfactory gland, and the majority of them are usually detected in the infranuclear portion and foot processes. These dense bodies have for the most part a heterogeneous internal structure, suggesting that they may be lipofuscin granules.

Light and electron microscopical basis for a faint yellow to brown color exhibited by vertebrate olfactory mucosa has been argued recently by GRAZIADEI (1972) in his review on vertebrate olfactory mucosa. As the consequence of his electron microscopic study on mouse olfactory mucosa, FRISCH (1967) expressed the opinion that 
extensive smooth and rough membranous systems and secretory products of both supporting cells and Bowman's gland cells indicate a high lipid content that may well be expected to give a yellowish tint to these cells and thus to the entire mucosa. The presence of a large amount of lipofuscin pigment in infranuclear and basal portions of supporting cells might essentially be responsible for yellow coloring of olfactory mucosa, although the present study has also revealed the occurrence of similar dense bodies, probably lipofuscin granules, in variable but smaller numbers in olfactory cell perikarya and olfactory glandular cells, indicating their byplay in yellow coloring. There are, however, no definite grounds on which the opinion of FRISCH (1967) may reasonably be opposed.

The most important and essential role of supporting cells in the physiology of the establishment of olfaction may probably consist in that they may serve as insulators between neighboring olfactory cells or neurons. As clearly shown in cross sections of the olfactory epithelium, olfactory cells appeared as if they were embedded among cytoplasmic masses of supporting cells, being separated from one another by supporting cell cytoplasm except on rare occasions, on which olfactory cells are contiguous to each other. It may be a noteworthy evidence that between contiguous supporting cells themselves and between these and olfactory cells there are close parallel appositions of plasma membranes separated by an intervenig intercellular space about $200 \AA$ across. Intercellular interdigitations of apposed plasma membranes have not been revealed anywhere between epithelial cells of bat and rabbit olfactory epithelium. Here it is a question whether excitations of olfactory cells can be transmitted to the contiguous supporting cells through these apposed plasma membranes with an intervening $200 \AA$ wide space in between.

\section{Olfactory cell}

Olfactory cells are considered to be olfactory receptors or sensory cells, and are taken for bipolar neurons within the olfactory epithelium, belonging to a typical pseudostratified columnar epithelium. Their perikarya, which contain round nuclei, are situated in a wide range between nuclei of supporting and basal cells. A distal slender process protruding from perikaryon toward the free surface of the olfactory epithelium is referred to as dendrite, and the proximal one descending toward the basal surface of the epithelium as neurite, which is thought to extend without ramification through the underlying connective tissue layer until arriving at the olfactory bulb of the central nervous system.

Dendrites extend beyond the free surface of the olfactory epithelium, terminating within mucous film and making a swelling called the olfactory vesicle, which is, in bat and rabbit, a conspicuous spherical or oval swelling measuring approximately $1-2 \mu$ in diameter. The author of this paper proposes to use the name "dendritic bulb" in place of "olfactory vesicle," because the latter seems to remind us readily of structures of much smaller orders. The constricted proximal portion of the dendritic bulb, called "neck" is connected side by side with the distal end of neighboring supporting cells or occasionally with the neck of a contiguous olfactory cell by means of a junctional complex. Direct contacts between olfactory cells at the level of the dendrite seems to be not so rare in bat and rabbit as recently discussed by GRAZIADEI (1972).

The spherical or oval dendritic bulb (olfactory vesicle) contains, within the cyto- 
plasm, basal bodies of olfactory cilia, microtubules, smooth membrane-bound vesicles and scanty mitochondria. Microvilli which were observed by several authors in the olfactory vesicles of some vertebrate species (BANNISTER 1965, 1968; ANDREs, 1969; GRAZIADEI, 1972 etc.) have not been detected in bat and rabbit. The basal bodies and olfactory cilia have attracted the special attention of investigators engaged in the electron microscopic study of the olfactory epithelium in a variety of vertebrate species. The reason why olfactory neurons possess such a dilation as an olfactory vesicle (dendritic bulb) at the distal end of dendrities beyond the level of the epithelial surface may consist in that the olfactory neuron may be able to bear on the distal end of the slender dendrite numerous olfactory cilia extending toward all directions within the mucous film. According to GRAZIADEI (1972), the number of olfactory cilia originating from one olfactory vesicle varies in different receptors of the same species and from species to species, but the usual ciliary number varies in the range of 10-15 per receptor. The number of cilia naturally corresponds to that of basal bodies. In the bat and rabbit olfactory receptor, numbers of basal bodies contained in several sections of dendritic bulbs were counted by the author, and the results gave the number per each olfactory receptor ranging between 20-30. This is far smaller than 100-150 per receptor in the dog, as estimated by OKano et al. (1967).

As reviewed by GRAzIADEI (1972), olfactory cilia (hairlets) have been electron microscopically investigated in a variety of vertebrates by many authors such as Bloom (1954), Brettschneider (1958), Yasutake (1959), De Lorenzo (1960), Reese (1965), Y амамото et al. (1965), AndRes (1969) and others. As pointed out by Frisch (1964a, b, 1965, 1967), ReEse (1965), Okano et al. (1967), the proximal thick portion (segment) of olfactory cilia tapers away in a long thin extension, which shows dilations along its long course. These two characteristics of olfactory cilia have also been confirmed in the present study; the proximal thick portion about $1 \mu$ long is as thick as ordinary non-sensory motile cilia, and contains a set of $9+2$ fibrils (tubules), while in the following long distal thin portion, the 9 peripheral doublet fibrils (tubules) and the 2 central fibrils (tubules) can not be distingished, only a few single tubules being scattered randomly in the matrix. In spindle-shaped dilations (swellings), a few single tubules are found along the plasma membrane and a few vesicles in the interior of the matrix. The question whether a terminal dilation as observed by OKANO (1965) in the dog olfactory cilium is also present in bat and rabbit has not been answered.

As is widely accepted, peripheral doublet tubules or fibrils extend continuously through the neck (original region) of the proximal thick portion to the electron dense wall or shell of the basal body, while 2 central tubules do not reach the basal body, disappearing before entering into the neck, although Okano (1965) described in his study of dog olfactory cilia that central tubules entered into the neck or original region of thick portion of cilium, though missing partially. He also observed, in cross sections of the original region (neck) of the thick portion, Y-figured linear densities which connected 9 peripheral doublets and the plasma membrane of the cilium, bifurcating into two branches before attachment to the latter. Similar electron dense configurations (radial arms or bridges; REESE, 1965) have been frequently identified in cross sections of proximal thick portions of bat and rabbit olfactory cilia. In ordinary non-sensory motile cilia, these linear $\mathrm{Y}$-shaped configurations are thought to be confined, as OKANo (1965) described, to the neck (original region) of the ciliary shaft 
(ITO and IshII, 1970), while in bat and rabbit olfactory cilia they are frequently observed not only in cross sections of the neck but also in those of the thick portion containing two central tubules. These configurations thus seem not to be restricted, in these species, to the neck but to be distributed more widely in the proximal thick portion of olfactory cilia.

Basal bodies of bat and rabbit olfactory cilia show the same fine structures as observed in ordinary motile cilia, and in olfactory cilia of other vertebrate species (GRAZIADEI, 1972). In bats and rabbits, basal bodies are associated with 3 types of accessory structures or appendages_-9 spokes, basal foot and rootlet.

Nine electron dense filaments arise from the distal ends of the 9 triplet tubules of the basal body in ordinary, non-sensory motile cilia to attach, by their somewhat thickened but finally pointed distal end, to the plasma membrane of the free cell surface. This filamentous apparatus is designated as a spoke (FLOck and Duvall, 1965) or transitional fiber (GibBons, 1967; Ueki, 1967). Nine spokes show a pinwheel-like configuration in a cross section of the distal end of the basal body. A similar structure of 9 spokes, emanating radially from each triplet has been demonstrated in basal bodies of bat and rabbit olfactory cilia. Okano (1965) and Okano et al. (1967) have demonstrated identical pinwheel-like configurations in transverse sections of basal bodies of canine olfactory cilia, and they regarded them, perhaps erroneously, as basal feet. GrAZIADEI (1972) pointed out in his review on olfactory mucosa that basal feet, when multiple, did not exhibit symmetry. BAnNisTer (1965) revealed, in an electron microscopic study on the teleostean olfactory surface, the simultaneous occurrence of a usual conical basal foot and the pinwheel-like configuration probably of the spokes in a one and the same cross section of a basal body (see Figure 11 in this paper). REese (1965) observed, in the basal bodies of the frog olfactory cilia, conical basal feet and pinwheel configurations of transitional fibers (spokes), and he showed them in several electron micrographs.

In basal bodies of ordinary, non-sensory motile cilia, the basal foot (satellite) has been observed by many investigators (ITO and IsHII, 1970). According to them, the basal foot is a conical process standing with its basis on the lateral surface of the basal body and extending at about right angles to its long axis toward a definite direction. Most investigators have reported the existence of cross striations similar to those found in the rootlet of the basal body. According to the review of GRAZIADEI (1972), in most vertebrate species, each basal body has one or more basal feet, but in some, e.g. mouse (FrISCH, 1967), they seem to be absent, although he has confirmed their presence in one specimen. Bannister (1965), Reese (1965) and Farbman and Gesteland (1974) have observed basal bodies of olfactory cells in teleostean fish, frog and mud puppy, and they confirmed the occurrence of a cross-striated basal foot pointing toward the center of the ciliated tip or olfactory vesicle of the olfactory cell. In bat and rabbit olfactory cells, basal bodies usually bear one or occasionally two conical basal feet, composed of fine filaments and exhibiting cross striations similar to those of rootlets. Their somewhat tapered end parts are usually oriented toward the center of the dendritic bulb (olfactory vesicle). In these respects the basal foot of the basal body of mammalian olfactory cilia morphologically agree with that in lower vertebrates. If the direction pointed by the tapered end of the conical basal foot, as proposed by some investigators (Iто and IsнII, 1970), indicates the direction of ciliary beat, 
much more detailed studies on it may be necessary in a variety of vertebrate species.

As summarized by GRAZIADEI (1972), the rootlet is not a constant appendage of the basal bodies of olfactory cilia; it is very long in birds and reptiles (GRAZIADEI, 1972), and short in frogs and dogs (REESE, 1965; OKano et al., 1967). More recently, FARBMEN and GEsteland (1974) could not reveal ciliary rootlets in the olfactory cells of the mud puppy, while ANDREs (1969) demonstrated relatively long rootlet fibers in cat olfactory cilia.

In bat and rabbit olfactory receptors, the rootlet is not a constant structure; it is rather a rare appendage. It is a slender fiber, measuring about $1.2 \mu$ in length and composed of a bundle of fine filaments. Arising from the proximal end of the basal body, it extends toward the neck of the olfactory vesicle (dendritic bulb), tapering toward its proximal end exhibiting cross striations at about $700 \AA$ intervals. In these fine structural respects, the present findings of the rootlet agree with the observations by OKANo et al. (1967) and ANDREs (1969) in canine and cat olfactory cells, respective1y. Rootlet fibers as revealed by REESE (1965) in frog olfactory vesicles, however, showed no cross striations. In tracheal ciliated cells of some mammals, a striated rootlet is a constant appendage of all basal bodies, while it is cempletely missed in others (ITO and IsHII, 1970). On account of this, some investigators have attributed an unessential functional significance to it such as a mechanical support of the basal body.

According to REESE (1965), olfactory cilia of the frog olfactory cell differ from typical motile cilia in that they have centrioles near their basal bodies which are provided with one basal foot. ANDREs (1969) occasionally observed in the proximal part of cat olfactory vesicles a few centrioles which did not send out cilia. Such independent centrioles are not verified in bat and rabbit dendritic bulbs, but it seems necessary to examine as many dendritic bulbs as possible to verify their existence.

Main organelles of the dendrite and the neurite (axon) of olfactory cells are, as observed by many investigators in several vertebrates, longitudinally oriented microtubules (neurotubules) and mitochondria. Other organelles found in the perikaryon, e.g. Golgi complex, Nissl substance, dense bodies (probably lipofuscin granules) and large multivesicular bodies, are few in both processes.

Almost all investigators engaged in electron microscopic studies on the olfactory receptors in various vertebrate species have not revealed the presence of neurofilaments either in dendrite or in neurite (SEIFERT and Ule, 1967; OKANo et al., 1967; FRISCH, 1967; GRAZIADEI, 1972). Nor is it verified in bat and rabbit olfactory cells. In this respect, bipolar neurons of olfactory epithelium are thought to differ from ordinary neurons.

Longitudinally oriented microtubules (neurotubules) in the dendrite extend into the dendritic bulb, where their round or elongated profiles are concentrated near the basal bodies. However, direct connections between neurotubules and basal bodies or basal feet as observed by BANNISTER (1965) in teleostean fish olfactory cells have not been ascertained.

Cytological differences between dendrite and neurite in bat and rabbit olfactory cells consist of the following three points: First, the dendrite, except the dendritic bulb, contains more numerous mitochondria elongated longitudinally; and second, Nissl substance consisting of rough endoplasmic reticulum and free ribosomes is 
demonstrated neither in dendrite nor in axon, but sparse free ribosomes are detected only in the dendrite, gradually increasing in amount toward the zone transitional to the perikaryon. The third difference concerns the occurrence of "large dense-cored vesicles" exclusively in the axon. These dense-cored vesicles measuring approximately $750-1,000 \AA$ in diameter have been for the first time demonstrated by the present author in the perikaryon and axon of bat and rabbit olfactory cells, and are assumed to have been elaborated by the Golgi complex in the perikaryon, to be discharged into the axon and transferred by means of axon flow toward the synaptic terminals in the olfactory bulb (bulbus olfactorius). Recently KuDo (1971) reported the large dense cored vesicles in his electron microscopic study on the autonomic ganglion in the chicken pancreas and attempted a detailed discussion on this subject. Dendrites, however, are free of the vesicles in question.

Nissl substance confined to perikaryons of bat and rabbit olfactory neurons shows characteristic fine structural features as observed in ordinary neurons (AkIyAma, 1960; Ekholm and Hyden, 1965; Kudo, 1971; OnA, 1974); it consists of as is widely known, flattened cisternae of rough endoplasmic reticulum and free ribosomes (polysomes), but the amount of ribosomes attached to membranes of endoplasmic reticulum is relatively small in contrast to the large amount of free ribosomes distributed among the flattened cisternae of rough endoplasmic reticulum, which frequently show the so-called lamellar patterns.

These fine-structural features shown by olfactory cells (recepsors) seem to be favorable for the assumption that they may be neurons situated within the olfactory epithelium.

\section{Basal cell}

As revealed by the present and other studies, the most common morphological features of basal cells are the following two: they have many attenuated cytoplasmic processes extended in variable directions, especially toward the basement membrane (Frisch, 1967; FARBMEN and Gesteland, 1974); and their processes and cell body embrace bundles of axons of the olfactory cells. Conspicuous cytological characteristics of basal cells, clarified in the present study, are that they contain abundant free ribosomes, some of which form polysomes, being distributed in the relatively narrow cytoplasmic layer around a relatively large nucleus and in cytoplasmic processes. In contrast to abundant free ribosomes, cisternae of rough endoplasmic reticulum are sparse. The same cytological features of basal cells have been pointed out by SEIFERT and Ule (1967), who, in accordance with RHODIN (1963), GRAZIADEI (1972) and the present author, have considered basal cells as undifferentiated elements in the olfactory epithelium. However, an unfavorable evidence against this opinion has been gained by YAMAмоTo et al. (1965) FrISCH (1967) and GRAZIADEI (1972), who have demonstrated in basal cells tonofilaments, which occasionally made prominent bundles. The present study demonstrated in some basal cells well-developed tonofilaments which gathered into bundles, extending in random directions and ramifying in simple fashion, but in others they were almost lacking. These basal cells lacking in tonofilament are thought to correspond to undifferentiated cells present in the olfactory epithelium. While SEIFERT and UlE (1967) have frequently observed mitosis in the basal cell layer, this has not been confirmed in the present study. 


\section{Interstitial or intercalated cell}

The present study has revealed a number of irregular-shaped cells with pale cytoplasm surrounding a relatively large nucleus of pale appearance due to poor chromatin content; they are found in bat olfactory epithelium among olfactory and supporting cells. These cells reach neither the luminal nor the basal surface of the olfactory epithelium, and their location is confined to the region between perikaryons of olfactory cells and the basal cell layer. On the basis of this location, they are called "interstitial" or "intercalated cells." The cells are characterized by abundant free ribosomes in contrast to scanty cisternae of the rough endoplasmic reticulum. Aside from such organelles, the cells contain a small Golgi complex in the supranuclear area and short mitochondria randomly scattered in the cytoplasm. From these cytological characteristics, it has been concluded that these cells must be undifferentiated cells in the olfactory epithelium. In the present study two mitotic figures, certainly of these cells, have been demonstrated. It is therefore reasonably assumed that intercalated cells may be probably arise from undifferentiated basal cells which may have preexisted in the olfactory epithelium having passed through mitotic divisions.

Stem cells of differentiated supporting and/or olfactory cells have been supposed by several investigators; they have been termed by various names such as forth type cells (OKANO, 1965; OKANo et al. 1967), blestema cells (ANDRES, 1966), undifferentiated basal cells (SEIFERT and UlE, 1967), fifth type cells (ANDREs, 1969), basal cells or stem elements (Graziadei and Metcalf, 1970, 1971), staminal cells (Graziadai 1972). They are mostly present in the basal cell layer of the olfactory epithelium, but fourth type cells of OKANo (1965) and fifth type cells of ANDREs (1969) are thought to be somewhat differentiated cells found in canine and cat olfactory epithelium, respectively, because their free apical ends provided with less numerous short microvilli extend up to the free surface of the olfactory epithelium. OKano and OKano et al. have considered the fourth type cells to be the precursors or juvenile forms of supporting cells. ANDREs (1969) has not only confirmed occurrence of the fourth type cells, but also found fifth type cells in cat olfactory epithelium, whose cell bodies contain nuclei among the perikarya of the olfactory cells. Their thin distal process reaches the free surface of the olfactory epithelium and is provided with straight stiff microvilli containing long axial filaments in contrast to those of supporting cells and fourth type cells. He has paid attention to the fact that these cells occur most frequently in the border region of the olfactory epithelium. Although AndREs (1969) has compared the fifth type cells with particular receptor-type cells which are provided with microvilli such as identified by BANNISTER (1965) in fish olfactory mucosa, they have many ultrastructural resemblances to the so-called "brush cells" found in the ciliated tracheal epithelium of rat, rabbit and man (Rhodin and Dalmamn, 1954, 1956; Brettschneider, 1958; Rhodin 1966; Konradova, 1966; Meyrick and ReId, 1968 etc.). Interstitial or intercalated cells proposed by the present auther are thought to be more undifferentiated cells, because they extend neither to the apical surface nor to the basal surface of the olfactory epithelium, and the question whether they would differentiate into receptor cells or into supporting cells is hardly answered; they could also be taken for precursors of the fourth type cells as proposed by OkANO. 


\section{Olfactory gland (Bowman)}

Olfactory glands have been thought to possess a short excretory duct within the olfactory epithelium (Toyoda, 1960). In the present study it has been proved in bat olfactory mucosa that epithelial cells of probably the intraepithelial duct of the olfactory gland possessed secretory granules identical with those found in the secretory portion of the olfactory gland, suggesting their secretory function. SEIFERT and ULE (1967) and BREIPOHL (1972) have demonstrated dark granules in the duct epithelial cells of mouse olfactory gland, and the latter author could hardly deny a secretory activity of the duct epithelium. In olfactory glands of a variety of mammalian species, the existence of an intraepithelial duct surrounded by proper epithelial cells having no secretory function seems to be doubtful.

The secretory portion of the olfactory gland is divided into two continuous parts -a short intraepithelial secretory portion existing within the olfactory epithelium and an extraepithelial secretory portion present in the connective tissue layer underlying the olfactory epithelium. The latter is referred to as the main secretory portion of the olfactory gland. Along the basal surfaces of the intra- and extraepithelial secretory portions facing the surrounding olfactory epithelium and connective tissue, respectively, a basal lamina has been scarcely demonstrable in accordance with the observation of FRISCH (1967) in mouse olfactory gland but in discordance with a positive result obtained by BREIPOHL (1972) in the same animal. Secretory cells showed hardly any cytological distinctions between intra- and extraepithelial location, or between bat and rabbit olfactory gland, except a few particular findings in the latter.

Several authors, dealing with cytology of the olfactory gland, have classified its secretory cells into two or three types (FrISCH, 1967; SEIFERT and UlE, 1967; SEIFERT, 1970; BREIPOHL, 1972), which seem to represent different functional stages of one kind of secretory cell. The secretory cells of bat and rabbit olfactory glands are found in different functional states - empty, restitution and repletion — on account of variable amounts of secretory granules, but the presence of distinct cell types such as dark and light cells has not been confirmed. In his light microscopic observation of olfactory glands in several mammalian species, ToyodA (1960) has classified secretory cells into large dark and small light cells, and considered them to represent different developmental or differentiated states of one and the same kind of cell. Thus he has taken small light cells for immature secretory cells with low secretory activity and large dark ones for mature and active cells containing many secretory granules. Furthermore, he has confirmed the existence of transitional forms between the two developmental stages. The small light cells described by Toyoda (1960) seem to correspond to the light cells described by FRISCH (1967), which are characterized, according to his electron microscopic observation, by extensive granular endoplasmic reticulum, while the large dark cells of Toyoda seem to correspond to Frisch's dark cells, which are characterized by many secretory granules and a vast amount of smooth endoplasmic reticulum (FRISCH, 1967).

As rightly cristicized by GRAZIADEI (1972), very little is known about the ultrastructure of the olfactory gland, and the best description in this field can be found in the paper of FRISCH (1967) on mouse olfactory mucosa. 
In fine structural characteristics, secretory cells of bat and rabbit olfactory glands are closely similar to the supporting cells of olfactory epithelium in these animals; they are characterized, as pointed out by GRAZIADEI (1972), by a large amount of tubular components of smooth endoplasmic reticulum, which are densely distributed throughout the cytoplasm and which in secretory cells of repletion stage, tightly fill up cytoplasmic layers between secretory granules. On the contrary, cisternae of rough endoplasmic reticulum and free ribosomes are relatively small in amount. Whorl-like configurations of concentrically packed tubules of smooth endoplasmic reticulum around mitochondria or their remnants as observed by FRISCH (1967) in the secretory cells of mouse olfactory gland have been confirmed neither in bat nor in rabbit, though in their supporting cells similar structures have occasionally been found. The second characteristic structures of the secretory cells of bat and rabbit olfactory gland are electron-lucent secretory granules with a coarsely granular or fibrillar matrix. They frequently contain a denser round core. These ultrastructural characteristics of the secretory granules of the olfactory gland have already been pointed out or shown in electron micrographs by FRISCH (1967) and BreIPOHL (1972) in mice. From the above findings, it seems evident that the secretory cell of bat, rabbit and mouse olfactory gland resembles, in ultrastructural characteristics of secretory granules, the supporting cells of the olfactory epithelium in lower vertebrates such as frog and box turtle, since in these animals, GRAZIADEI (1972) has demonstrated secretory granules of supporting cells with similar ultrastructural characteristics. On the contrary, secretory cells of the box turtle olfactory gland which are rich in rough endoplasmic reticulum and which contain highly electron dense secretory granules (GRAZIADEI, 1972) may be quite different from those of bat, rabbit and mouse olfactory gland; they rather resemble serous or albuminous secretory cells.

The secretory granules of the olfactory gland of bat and rabbit are bounded by a distinct limiting membrane, which is frequently fragmented, and they are not infrequently in coalescent state.

Aside from smooth- and rough-surfaced endoplasmic reticulum and variable numbers of secretory granules, bat and rabbit olfactory gland cells contain numerous mitochondria, well-developed Golgi complexes in the supranuclear area, an occasional centriole in the apical cytoplasm, occasional filaments and microtubules and a number of probable lysosomes or lipofuscin granules (ToyodA, 1960). Lipofuscin granules may contribute, as already discussed above, to yellow coloring of the olfactory mucosa.

It has become common knowledge in the cytology of secretory cells that in the formation process of secretory granules, the Golgi complex may play an essential role in the condensation and packaging of secretory material, which has been synthesized in endoplasmic reticulum and transferred by vesicles to this organelle (NEUTRA and Leblond, 1966; Freeman, 1966; Berlin, 1967). However, the process of secretory granule formation in secretory cells of the olfactory gland has remained almost untouched until today, and only FRISCH (1967) discussed a little on the relation of the Golgi complex to the formation of secretory granules in secretory cells of the mouse olfactory gland, saying that there is usually the proximity of this organelle to secretory granules, which indicates the possibility that the Golgi apparatus may play some role in elaboration of the product.

Upon careful observations of the Golgi complexes of the secretory cells of bat 
and rabbit olfactory gland, the author has confirmed the formation process of the secretory granules in the Golgi area as suggested by FRISCH (1967). The Golgi complex consists of Golgi lamellae comprising a stack of flattened cisternae, Golgi vacuoles and many Golgi vesicles around the lamellae with a small number of coated vesicles intermingled. Some of these coated and non-coated vesicles are often found adhering to one end of flattened cisternae of the Golgi lamellae, suggesting, that vesicles may transfer secretory materials elaborated in smooth or rough, or probably both, endoplasmic reticula, or materials ingested from the extracellular space to the Golgi lamellae. Golgi vaculoes contain a small amount of loosely fibrillar material, which is also found in the expanded portions of the Golgi lamellae. Close to these vacuoles, there are found small immature secretory granules, which are somewhat larger and contain more compact fibrillar material, indicating that Golgi vacuoles may gradually transform into immature secretory granules; thereby, concomitant with the growth of Golgi vacuoles (condensing vacuoles), loosely fibrillar content may increase in amount thus becoming more condensed within the vacuoles.

In mammalian species in which supporting cells of the olfactory epithelium have no secretory function, the so-called mucous film covering the free surface of the epithelium must be composed merely of the secretory product of the olfactory gland. As discussed above, the ultrastructural characteristics of secretory granules of the bat and rabbit olfactory gland seem to speak for the hypothesis that the olfactory gland may be mucous; at least the view that it may belong to the serous gland seems not tenable. Several histochemical tenchniques such as toluidine blue staining, PAS as well as Bauer's method, alcian blue and ruthenium red (LUFT, 1971) staining consistently give results in favor of the view that the olfactory gland of bat and rabbit may be mucous as claimed by Toyoda (1960) in his light microscopic observation. This question of whether serous or mucous, has been argued by many investigators (BAradi and Bourne, 1953; Allison, 1953; Mira, 1963; Moulton and Beidler, 1967; BREIPOHL, 1972; GRAZIADEI, 1972 and others).

As justly pointed out by FRISCH (1967), the cytological evidence that secretory cells of the olfactory gland contain a large quantity of smooth endoplasmic reticulum with relatively small amounts of rough endoplasmic reticulum seems to be important because smooth endoplasmic reticulum has been believed to play an essential role in the elaboration of steroid hormones in endocrine cells such as adrenocortical cells (Long and Jones, 1967 etc.), interstitial cells of the testis (YAMADA, 1965; NAGAno, 1965 etc.), as well as ovarian lutein cells (SAto and Kurosumi, 1965) while on the other hand, it participates in the carbohydrate metabolism. In contrast to secretory cells of the olfactory gland, mucous cells such as goblet cells in the epithelia of various organs usually possess well-developed rough endoplasmic reticulum with poor smooth endoplasmic reticulum. Although as noted by FRISCH (1967) the unique ultrastructural characteristics of the secretory cells of bat and rabbit do not justify an assumption that they may elaborate lipid secretion, it seems possible that they may secrete a mucous substance more or less different from ordinary mucous in that it may perhaps contain lipid components. Until today, there have been no authors who claim that the olfactory gland secretes a mucous rich in lipid components. Allison (1953), however, maintained that the olfactory gland might be a particular gland which resembels neither serous nor mucous glands, secreting material of unknown nature, 
and Moulton and Beidler (1967) proposed from the viewpoint of morphology and histochemistry, that Bowman's gland was not identified either as a serous or mucous gland. The present author can only conclude here that on the basis of the ultrastructural and histochemical properties of secretory granules, bat and rabbit olfactory glands may be considered as a kind of mucous gland, but that cytological features of the cytoplasm of secretory cells suggest an unknown special nature of their mucous secretory product.

As for the mechanism of discharge of secretory granules from the secretory cells into the glandular lumen, scarcely any electron microscopic investigators of the olfactory gland have ever commented on it, with only the exception of ToyodA (1960), who has pointed out, in his light microscopic study on olfactory glands of various mammals, the occurrence of apocrine secretion in secretory cells.

Among several mechanisms of discharge of secretory granules into extracellular space (KuRosumi, 1961), the so-called emiocytotic or reverse-pinocytotic process has been most widely confirmed both in exocrine and endocrine glands. In both bat and rabbit olfactory glands, secretory granules elaborated in the Golgi area show a tendency to migrate toward the luminal area of the secretory cells to be found immediately beneath the plasma membrane lining the luminal surface, but actual cytological signs indicating their emiocytotic discharge into the glandular lumen have not been verified in the present study, although it has been revealed by some authors in mucous cells, for example in goblet cells (ITo and IsHII, 1970).

Cytological findings which suggest the release of a secretory product by diacrine and apocrine mechanism have frequently been confirmed especially in the rabbit olfactory gland. In both bat and rabbit olfactory glands it has frequently been revealed that limiting membranes of secretory granules are fragmented and that their matrices have permeated through the discontinuties into the cytoplasm of secretory cells. In the rabbit olfactory gland, it is shown that the secretory material liberated in the cytoplasm of secretory cells flows toward the luminal side and is accumulated there to make a wide protuberance bulging into the glandular lumen. Thus, the secretory material is thought to be discharged probably by diffusion or diacrine mechanism into the glandular lumen through the plasma membrane lining the protuberance. The matrix or cytoplasm of the protuberance is electron lucent and fine fibrillar and resembles both the matrix of secretory granules and secretory substance within the glandular lumen, although it contains loosely distributed tubular components of smooth endoplasmic reticulum, scantly polysomes, several small vesicles and electron dense rodlets, derived probably from tubular components of smooth endoplasmic reticulum.

In rabbit olfactory glands, besides frequent wide protuberances bulging into the glandular lumen, more or less long, club- or tongue-shaped processes are protruded from the apical surface of the secretory cells far into the glandular lumen; and they are thought to be formed by the same mechanism as the protuberances, and their electron-lucent, fine fibrillar matrix contain the same organelles as found in the protuberances, excepting components of smooth endoplasmic reticulum. No secretory granules are found either in the protuberances or the tongue-shaped processes.

The tongue- or club-shaped process is supposed to be pinched off at the constricted neck by means of the so-called apocrine process, and to be discharged on the whole 
into the glandular lumen and subsequently dissolved there. In electron microscopic observations of supporting cells of the olfactory epithelium of lower vertebrates (box turtle and bullfrogs), in which these cells are known to possess secretory function, GrAzIADEI (1972) and TAKAGI and OKANO (1974) have shown, by electron micrographs, pictures indicating the occurrence of apocrine discharge of secretory materials.

As described above, rabbit olfactory gland cells are assumed to release their secretory product by means of the diacrine and apocrine mechanism, but the present study has failed to reveal cytological findings which indicate the discharge by means of emiocytosis or reversed pinocytosis, the most common releasing process of secretory granules in exocrine and endocrine glands. However, the possibility of emiocytotic release of secrotory granules in both the bat and rabbit olfactory gland has somehow been out of focus of close attention in the present study, but it should not of course be neglected.

In this study, a curious cytological finding has frequently been obtained in the secretory cells both in the intra- and extraepithelial secretory portion of rabbit olfactory glands. In contrast to the above mentioned apical processes, similar cytoplasmic processes are protruded from the basal surface of secretory cells into surrounding olfactory epithelium or connective tissue. These basal processes are thought to be formed probably by the same mechanism with apical processes, and they contain, in electron-lucent homogeneously fine fibrillar or granular matrix, the same organelles as in the apical processes; but they differ from the latter in the absence of electrondense rodlets. The fate and functional significance of the basal tongue-shaped processes have not been clarified in the present study.

ToyodA (1960) observed in his light microscopic study on the olfactory glands of a variety of mammals, areas occupied by a homogeneous hyaline substance in the basal and paranuclear portion of principal secretory cells which are stained with eosin and which contain neither mitochondria nor socretory granules. The present electron microscopic study has suggested these homogeneous hyaline areas to corresponds perhaps to the lateral and basal part of secretory cells of the rabbit olfactory gland, where the distribution of tubular components of smooth endoplasmic reticulum and secretory granules sometimes become loosened as described above. The apical zone of the cytoplasm and also protuberances bulging into the glandular lumen are thought to appear, in light-microscopic observations, as homogeneous hyaline areas because of the lack in secretory granules and the loose arrangement of tubular components of smooth endoplasmic reticulum. The apical and basal processes might also present similar appearances in light-microscopy.

The so-called "dense rodlets" which are observed within the protuberances and processes of the secretory cells of the rabbit olfactory gland are minute rod-shaped structures which are for the first time reported in the present study. As for their origin and nature, it is assumed that they may probably be elaborated by pinching off or fragmentation from tubular components of smooth-surfaced endoplasmic reticulum. They contain an electron dense material, which is probably synthesized within the smooth endoplasmic reticulum. They are bounded by a limiting membrane and found in considerable number among secretory granules in cytoplasmic areas near the apical portion of secretory cells. Between dense rodlets and electron-lucent tubules of smooth endoplasmic reticulum, there are transitional forms containing materials 
of various intermediate densities. Therefore, it is supposed that dense rodlets may migrate toward the apical cytoplasm to enter into the apical protuberances and processes, and may presumably be discharged by means of the apocrine mechanism into the glandular lumen. It is of interest that they are not demonstrated in the basal tongue-shaped processes above mentioned.

The present study, therefore, has suggested that dense rodlets may be discharged into the glandular lumen by means of the apocrine mechanism simultaneously with the secretory substance derived from secretory granules thus supporting the hypothesis that the product elaborated in the smooth endoplasmic reticulum, which is surprisingly developed in the secretory cells of the olfactory gland, may at least partially be released by means of this mode into the glandular lumen. However, it should be kept in mind that dense rodlets in question have failed to be revealed in the secretory cells of the bat olfactory gland.

Acknowledgement. The author wishes to express his cordial thanks to Prof. Toshio Iто for his encouragement and valuable suggestions during the course of this study and for his help in the preparation of this manuscript. He is also grateful to Prof. Kazuko UcHIDA for reading this manuscript.

\section{コウモリとウサギの嗅粘膜の電子顕微鏡的研究}

$$
\text { 山本将 }
$$

コウモリとウサギの嗅上皮は 4 型の細胞から成る.

1. 支持細胞は多量の滑面小胞体をもつが，分泌機能はない. 支持細胞の自由表面から 出る多数の長い微絨毛には軸系はない。微絨毛と細胞の自由表面を包む形質膜の外葉から 出る 多くの微細な泡状突起が 新らしく証明された. 頸部と直径 約 $200 \AA$ の先端膨大部 から成り，おそらく支持細胞の表面積の拡大と 微細アポクリン分泌機構による未知物質 の放出に与る.

2. 嗅細胞の核周部は上皮自由表面へ樹状突起を，上皮下部へ神経突起（軸索）を伸ば す。著者は樹状突起の olfactory vesicle (嗅小胞) dendritic bulb (樹状突起球) と呼 ぶことを提唱した．その中に含まれる嗅小毛の基底小体は 3 附属物をもつ．1）は dendritic bulb の中央に向かって出る 円錐形で横紋をもつ basal foot で，ときに 2 個ある．2) ほ同じ横絞をもつ $1.2 \mu$ 長の rootlet で，3）は 9 本の spokes で，基底小体の 9 triplets の遠位端と近接する形質膜を結合する。本研究で初めて大有芯小胞（直径 750-1,000 ̊) が嗅細胞の核周部と軸索とに証明された. 嗅細胞の樹状突起と軸索にほ神経微細管とミト コンドリアが豊富で，神経微原繊維は証明されない，樹状突起は遊離りボソームを含むが 大有芯小胞をもたず，軸索突起は大有芯小胞をもつがリボソームをもたない.

3. 微原繊維を欠く未分化基底細胞があり，それらが有糸分裂を経て，本研究で見出さ れた明るい間細胞へ分化すると想像される，間細胞は未分化細胞の特性をもち，おそらく 嗅細胞と支持細胞の前駆者である.

4. コウモリとウサギの嗅腺では，分泌機能をもたない固有の上皮内導管の存在は疑問 
である．腺の上皮内および上皮外分泌部に基底膜は証明されない．腺細胞は種々の分泌機 能時期にあるが，独立の型に分けることはできない，腺細胞は多量の滑面小胞体の細管要 素をもつが，粗面小胞体要素は少ない，暗い芯をもつ明るい分泌顆粒は，その組織化学的 性質と共に両哺乳動物の嗅腺の粘液腺説它支持するが，腺細胞に著しく滑面小胞体が多い 事実は，粘液性分泌物が特殊な化学的性質肎もつことを暗示する.ウサギの腺細胞にはお そらく滑面小胞体の細管に由来する “dense rodlets”があり，アポクリン分泌により腺腔 へ放出される.

\section{References}

Akiyama, Y.: Electron microscopic study on the spinal ganglion cell. Arch. histol. jap. 19: 411$436(1960)$.

Allison, A. C.: The morphology of the olfactory system in the vertebrate. Biol. Rev. 28: 195-244 (1953).

Andres, K. H. : Der Feinbau der Regio olfactoria von Makrosmatikern. Z. Zellforsch. 69: 140-154 (1966).

: Der olfactorische Saum der Katze. Z. Zellforsch. 96: 250-274 (1969).

Bang, B. G. and F. B. Bang: A comparative study of the vertebrate nasal chamber in relation to upper respiratory infections. Bull. Johns Hopkins Hosp. 104: 107-149 (1959).

Bannister, L. H.: The fine structure of the olfactory surface of teleostean fishes. Quart. J. microsc. Sci. 106: 333-342 (1965).

- Fine structure of the sensory endings in the vomeronasal organ of the slow-worm Anguis fragilis. Nature 217: 275-276 (1968).

Baradi, A. F. and G. H. Bourne: Gustatory and olfactory epithelia. Int. Rev. Cytol. 2: 289-330 (1953).

Berlin, J. D. : The location of acid mucopolysaccharides in the Golgi complex of intestinal goblet cells. J. Cell Biol. 32: 760-766 (1967).

Bloom, G.: Studies on the olfactory epithelium of the frog and the toad with the aid of light and electron microscopy. Z. Zellforsch. 41: 89-100 (1954).

Breipohl, W.: Licht- und electronenmikroskopische Befunde zur Struktur der Bowmanschen Drüsen in Riechepithel der weißen Maus. Z. Zellforsch. 131: 329-346 (1972).

Brettschneider, H. von: Elektronenmikroskopische Untersuchungen an der Nasenschleimhaut. Anat. Anz. 105: 194-204 (1958).

Bronshtein, A. A. and V. P. Ivanov : Electron microscopic investigation of the olfactorial organ in the lamprey. J. Evol. Biochem. Physiol. 1: 251-261 (1964).

De Lorenzo, A. J.: Electron microscopy of the olfactory and gustatory pathways. Ann. Otol. Rhinol. Laryngol. 69: 410-420 (1960).

Ekholm, R. and H. Hyden : Polysomes from microdissected fresh neurons. J. Ultrastr. Res. 13: 269-280 (1965).

Farbman, A. L. and R. C. Gesteland : Fine structure of olfactory epithelium in the mud puppy, Necturus maculosus. Amer. J. Anat. 139: 227-244 (1974).

Flock, A. and A. J. Duvall : The ultrastructure of the kinocilium of the sensory cells in the inner ear and lateral line organs. J. Cell Biol. 25: 1-8 (1965).

Freeman, J. A. : Goblet cell fine structure. Anat. Rec. 54: 121-148 (1966).

Frisch, D.: Ultrastructural observations of the mouse nasal and olfactory mucosa. Anat. Rec. 148: 283 (Abst.) (1964a).

- : An electron microscope study of nasal mucosa of the mouse. Doctoral Dissertation, New 
York Univ. Graduate School of Arts and Sciences, 1964b.

Frisch, D. : Ultrastructure of mouse olfactory mucosa. Anat. Rec. 151: 351 (Abst.) (1965).

: Ultrastructure of mouse olfactory mucosa. Amer. J. Anat. 121: 87-120 (1967).

Gibbons, I. R. : The (electron microscopic) organization of cilia and flagella (Anodonta cataracta, rat, Tetrahymena pyriformis, Arbacia zootermopsis, Juniperus. In: Molecular organization and biological function. New York and London, Harper and Row, 1967 (p. 211-237).

Graziadei, P. P. C. : The ultrastructure of vertebrates olfactory mucosa. In: (ed. by) Friedmann: The ultrastructure of sensory organs. American Elsevier, 1972.

Graziadei, P. P. C. and J. F. Metcalf : Autoradiographic study of frog's olfactory mucosa. Amer. Zool. 10: 559 (1970).

: Autoradiographic and ultrastructural observations on the frog's olfactory mucosa. Z. Zellforsch. 116: 305-318 (1971).

Hubert, J. P., J. Flament-Durand and P. Dustin : Centrioles and cilia multiplication in the pituitary of the rat after furosemid and colchicine treatment. I. The posterior lobe. Cell Tiss. Res. 149: 349-361 (1974).

Ito, T. and H. Ishii : Morphology of tracheal and esophageal mucosa (Japanese text). Tokyo, Hirokawa Publishing Co., 1970.

Kolmer, W.: Geruchsorgan. In: Möllendorff's Handbuch der mikroskopischen Anatomie des Menschen. Bd. III. Berlin, Springer, 1927. (p. 192-249).

Konradova, V.: The ultrastructure of the tracheal epithelium in rabbit. Fol. morphol. 14: 210214 (1966).

Kratzing, J. E. : The structure of olfactory cilia in a lizard. J. Ultrastr. Res. 39: 295-300 (1972).

Kudo, S.: Fine structure of autonomic ganglion in the chicken pancreas. Arch. histol. jap. 32: 455-497 (1971).

Kurosumi, K.: Electron microscopic analysis of the secretion mechanism. Int. Rev. Cytol. 11: 1-124 (1961).

Long, J. A. and A. L. Jones: Observations on the fine structure of the adrenal cortex of man. Lab. Invest. 16: 355-370 (1967).

Luft, J. H.: Ruthenium red and violet. I. Chemistry, purification methods of use for electron microscopy and mechanism of action. Anat. Rec. 171: 347-368 (1971).

Meyrick, B. and L. Reid : The alveolar brush cell in rat lung-a third pneumocyte. J. Ultrastr. Res. 23: 71-80 (1968).

Mira, E. : Oxidative and hydrolytic enzymes in Bowman's glands. Acta otolaryngol. 56: 706-714 (1963).

Mizuhira, V.: The electron microscope-Application to medical biology (Japanese text). Tokyo, Ishiyaku Shuppan Publishing Co., 1973.

Moulton, D. G. and L. M. Beidler: Structure and function in the peripheral olfactory system. Physiol. Rev. 47: 1-52 (1967).

Nagano, T.: Some observations on the structure of interstitial cells and Sertoli cells of the human testis. Gunma Symp. Endocrinol. 2: 19-28 (1965).

Neutra, M. and C. P. Leblond : Synthesis of the carbohydrate of mucus in the Golgi complex as shown by electron microscope radioautography of goblet cells from rats injected with glucose $\mathrm{H}^{3}$. J. Cell Biol. 30: 119-136 (1966).

Okano, M. : Fine structure of the canine olfactory hairlets. Arch. histol. jap. 26: 169-185 (1965).

Okano, M., A. F. Weber and S. P. Frommes: Electron microscopic studies of the distal border of the canine olfactory epithelium. J. Ultrastr. Res. 17: 487-502 (1967).

Ona, A.: Cytological and electron microscopic studies on the vestibular ganglion cells of the bats (Japanese text with English abstract). Jap. J. Otol. 77: 203-216 (1974).

Porter, K. R. and M. A. Bonneville: An introduction to the fine structure of cells and tissues. 2nd ed., Philadelphia, Lee and Febinger, 1964.

Reese, T. S. : Olfactory cilia in the frog. J. Cell Biol. 25: 209-230 (1965). 
Rhodin, J.: Ultrastructure of the tracheal ciliated mucosa in rat and man. Ann. Otol. Rhinol. Laryngol. 68: 964-974 (1959).

Rhodin, J. and T. Dalhamn : The ultrastructure of the epithelial cells in the trachea of the albino rat. J. appl. Phys. 25: 1463 (1954).

Rhodin, J. and T. Dalhamn : Electron microscopy of the tracheal ciliated mucosa in rat. Z. Zellforsch. 44: 345-412 (1956).

Sato, T.: A modified method for lead staining of thin sections. J. Electron Microsc. 17: 158-159 (1968).

Sato, S. and K. Kurosumi : Electron microscopic studies on the fine structure of rat lutein cells with special reference to the intramitochondrial globules. Gunma Symp. Endocrinol. 2: 61-69 (1965).

Scott, J. E. and J. Dorling : Differential staining of acid glycosaminoglycans (mucopolysaccharides) by alcian blue in salt solutions. Histochemie 5: 221-233 (1965).

Seifert, K. und D. Ule : Die Ultrastruktur der Riechschleimhaut der neugeborenen und jugendlichen weissen Maus. Z. Zellforsch. 76: 147-169 (1967).

Takagi, S. F. and M. Okano: An electrophysiological and electron microscopical study of the secretion in the olfactory epithelium. Gunma Symp. Endocrinol. 11: 3-14 (1974).

Toyoda, M. : Cytologische und histologische Untersuchungen über die Gl. olfactoria bei vershiedenen Säugetieren. Arch. histol. jap. 20: 57-106 (1960).

Ueki, H.: Ultrastructure of the groups of ciliary basal bodies in the epithelial cells of human oviduct and its functional meanings. Acta anat. nippon. 42: 331-342 (1967).

Wesolowski, H.: The behavior of mitochondria and the secretion of the olfactory epithelial cells and the olfactory glands after pyridine stimulation in domestic birds. Fol. biol. 15: 303-324 (1967).

Yamada, E. : Some observations on the fine structure of the interstitial cell in the human testis as revealed by electron microscopy. Gunma Symp. Endocrinol. 2: 1-17 (1965).

Yamamoto, T., A. Tonosaki and T. Kurosawa: Electron microscope studies on the olfactory epithelium in frogs. Acta anat. nippon. 40: 342-353 (1965).

Yasutake, S.: The fine structure of the olfactory epithelium studied with the electron microscope. J. Kurume Med. Assoc. 22: 1279-1304 (1959).

\author{
山本 将 \\ 干173 東京都板橋区加賀 2-11-1 \\ 帝京大学医学部 \\ 第一解剖学教室
}

\author{
Masaru Yамамото \\ Department of Anatomy \\ Teikyo University School of Medicine \\ Kaga, Itabashi-ku \\ Tokyo, 173 Japan
}

